Article

\title{
Research on the Effects of Information Description on Crowdfunding Success within a Sustainable Economy-The Perspective of Information Communication ${ }^{\dagger}$
}

\author{
Xiaobei Liang, Xiaojuan Hu and Jiang Jiang * \\ School of Economics and Management, Tongji University, Shanghai 200092, China; \\ liangxiaobei@tongji.edu.cn (X.L.); huxiaojuan@tongji.edu.cn (X.H.) \\ * Correspondence: allenajj@tongji.edu.cn \\ + This paper is an extension of a conference paper entitled "Empirical Study of the Effects of Information \\ Description on Crowdfunding Success-the Perspective of Information Communication," which was honored \\ as the outstanding paper in the 18th International Conference on Electronic Business. About $65 \%$ of the former \\ content has been changed.
}

Received: 11 November 2019; Accepted: 10 January 2020; Published: 16 January 2020

check for updates

\begin{abstract}
Crowdfunding has been widely used by small and micro enterprises, which can raise funds through launching a project in crowdfunding platform. It is also beneficial to sustainable financing. What is more, the success of crowdfunding projects facilitates the sustainable development of those growing enterprises. In this study, from the perspective of information communication and based on information asymmetry and signaling theory, we identify three dimensions of information description, including information quantity (word count, picture count and video count), information attitude (as measured by comment), and information quality (readability and update). We empirically examine their direct effects on crowdfunding success and the moderating effect of information attitude using binary logistic regression. Data $(N=7207)$ is collected from Kickstarter, a popular crowdfunding platform. The results reveal that when considering these three dimensions of information description together, word count is associated with crowdfunding success in an inverted-U shape. Picture count, video count, comment, and update have positive effects on crowdfunding success. In contrast, readability is negatively related to crowdfunding success. In addition, we find that comment negatively moderates the effect of picture count on crowdfunding success. These findings show the significance of information description on crowdfunding success, bringing theoretical and practical insights for project creators.
\end{abstract}

Keywords: crowdfunding success; information communication; information description; information asymmetry; signaling theory

\section{Introduction}

As an innovative sustainable financing model, crowdfunding plays a crucial role in the sustainable development of growing enterprises, which has become increasingly popular and has attracted increased academic interest in recent years [1-8]. Crowdfunding is a group behavior in which the public communicates through the Internet and pools funds to support activities initiated by other organizations and individuals. So far, there are approximately 1250 active crowdfunding platforms across the world [9]. According to Massolution, the global crowdfunding industry reached $\$ 34.4$ billion USD in 2015, up from $\$ 6.1$ billion USD in 2013; the compound annual growth rate is expected to be $26.87 \%$ for the period of 2016-2020 [10]. Kickstarter and Indiegogo are the two largest crowdfunding 
platforms in the world. Up to 12 October 2019, on Kickstarter, 458,733 projects have been launched, and on Indiegogo, more than 650,000 projects have been launched. What is more, a large number of well-known large enterprises have launched projects in crowdfunding platforms to validate their market research through voting of real consumers or real transaction, such as Coca-Cola, P\&G, BOSE, MOTOROLA, Honeywell, and GE. On one hand, crowdfunding can help large companies verify market demand, and on the other hand, it facilitates companies to improve their products. Meanwhile, for small and micro enterprises, crowdfunding can help them raise funds and bring products to market. Therefore, crowdfunding has become a vital means for enterprises to solve problems. However, in a recent research report, Clifford [11] found that the failure rate of financing ranges from $69 \%$ (Kickstarter.com) to 87\% (Indiegogo.com) among the five largest crowdfunding platforms. This means that the actual completion rate of financing is low, and the financing success rate needs to be improved. Therefore, it is crucial to identify general antecedents of financing success or performance, because it can provide insights to project creators to improve the rate of crowdfunding success.

Previous studies have investigated the antecedents of crowdfunding success from different perspectives (the summary of related empirical researches is presented in Table A1). The antecedents of crowdfunding success can mainly be divided into three types. First, the creators-related factors are important influencers for crowdfunding success, including creators' experience and expertise [12-14], group size and composition [14-16], social capital [13,17-20], and human capital [2,21]. Second, the projects' internal characteristics and related outcomes, such as the goal [16,22], duration [16,22,23], category [24-27], rewards [16,22,23,28], have also been verified as antecedents that may affect the crowdfunding success. Finally, how the information of the projects is presented, namely the project's information description, has further been noted as an impactor that must be considered. In summary, previous studies have suggested three dimensions of information description, including information quantity (how many words [12,15,23,27,29-32], pictures [23,27,31,32], and videos [23,27,29,31] are used to describe the project), information quality (to what extent the project information is readable, namely readability [12]), and the frequency of information update, namely updates $[1,17,31,32]$ and information attitude (the backers' opinions or questions about the projects and the creators' replies are all reflected in the comments $[15,29,31]$. According to the prior literatures (as shown in Table A1), we can conclude that the effect of creators' related factors and the internal characteristics of projects on crowdfunding success have been fully verified. Compared with the hard conditions such as projects' and creators' characteristics, better information description is a soft mean that is relatively easier to achieve, which is a relatively low-cost way to pursue crowdfunding success. Although the effect of information description on crowdfunding success has also gained substantial attention, several shortcomings still exist. First, most of the related empirical studies have only focused on one or two dimensions of information description. Some have only examined the effect of information quantity [22,27,29,30,33,34], some have only concerned information quality [35-37], and some have only studied information attitude [38,39]. Second, although few researchers have considered all the three dimensions of information description as antecedents of crowdfunding success, they have only focused on one or two aspects of each dimension of information description. For example, Lagazio and Querci [15] and Petitjean [40] have only examined the effect of two aspects of information quantity on crowdfunding success. Finally, most of studies have only focused on the linear relationships between different dimensions of information description and crowdfunding success, and few have examined whether there exists non-linear relationships or moderating effects. In conclusion, as for the research on the relationship between information description and crowdfunding success, there is still a dearth of studies that consider all aspects of the three dimensions of information description and at the same time explore the non-linear and moderating effects. The research on the effects of information description on crowdfunding success is still lack a systematic approach and needs to be further expanded.

Based on the above, in this study, we explore the effects of information description on crowdfunding success from the perspective of information communication. We consider all three dimensions of information description, namely information quantity (word count, picture count, video count), 
information quality (readability, update), and information attitude (as measured by comment), as important influencers for crowdfunding success. On the basis of examining the linear effect of these three dimensions, we further explore whether there exists the inverted-U influence of words on crowdfunding success and the moderating effect of comments on the relationship between information quantity and crowdfunding success. Through the comprehensive investigation, we can help form a deeper and clearer understanding of the relative influence of the three dimensions of information description on crowdfunding success. To our best knowledge, this study is one of the first to investigate the moderating effects of comments.

Empirical data were collected from Kickstarter, and information from a total of 7207 projects was used in this study. We found that there is an inverted-U relationship between the number of words and crowdfunding success. Increasing the number of words is not always beneficial for funding success. Too many words in description can cause the burden of understanding projects for backers. The optimal level of word count in the project description is 2013. In addition, more pictures, videos, comments, and frequent updates are all beneficial for success. However, the surprising result is that readability negatively affects crowdfunding success. The results can provide suggestions on how to improve the information description of project to increase the possibility of project financing. First, multiple forms of information should be used in project description. Combining words, pictures, and videos can provide more detailed information. However, it is worth noting that the word count should be less than 2013, and creators should add more pictures and videos in description. Second, updating frequently, using formal words representing professionalism, encouraging backers to comment, and interacting with backers are all necessary during the fundraising. These suggestions help promote the financing efficiency of the crowdfunding industry and facilitate the sustainable development of small and micro enterprises.

This paper is structured as follows. First, we provide the literature review of current research relating to crowdfunding, information asymmetry, information communication, and signaling theory. Then, we develop a theoretical model, and the hypotheses are presented in a sequence. Next, we collect data from the Kickstarter website and present research methods and empirical results. Finally, the paper closes with a conclusion and discussion of the results' implications.

\section{Literature Review}

\subsection{Crowdfunding and Reward-Based Crowdfunding}

Crowdfunding is a new way of financing, which has become more and more popular in recent years. Compared with traditional investment, such as banks or venture capitalists, crowdfunding provides a bridge for fundraisers and individual investors [41]. Furthermore, the popularity of the Internet and e-commerce increases the trust of users on online transaction, which also makes it more possible for users to invest in projects via crowdfunding platforms. Moreover, crowdfunding has attracted enormous attention from scholars, who mainly focus on three areas.

First, prior studies have conducted qualitative research on crowdfunding, identifying the definition, business model, risk, and law of crowdfunding. The concept of crowdfunding first comes from crowdsourcing. Crowdsourcing is using the crowd to gain ideas, suggestions, and solutions to develop enterprises' activities [42]. Crowdfunding can be seen as an element of crowdsourcing, and crowdsourcing is a broader concept $[3,29,43,44]$. There are two frequently cited definitions of crowdfunding. Schwienbacher and Larralde [44] stated that crowdfunding is an open call, essentially through the Internet, for the provision of financial resources either in the form of donation or in exchange for some forms of reward and/or voting rights in order to support initiatives for specific purposes. Based on the definition of Schwienbacher and Larralde, Mollick [1] defined crowdfunding as the efforts taken by entrepreneurial individuals and groups to fund their ventures through drawing on relatively small contributions from a relatively large number of individuals using the Internet without standard financial intermediaries. Comparing the two definitions, we can conclude that 
Mollick [1] has defined crowdfunding from an academic point of view, which is narrower. Moreover, as a new Internet-based financing model for microfinance $[3,29,45]$, crowdfunding can be divided into four categories. The first is patronage-based crowdfunding, where supporters do not expect direct return from their contributions or donations. The second is lending-based crowdfunding, where the supporters expect some rates of return on their capital invested. The third is reward-based crowdfunding, where supporters receive a reward for backing a project. The last is equity-based crowdfunding, where the supporters are treated as investors and are given certain shares of future profit of the project [1]. Some scholars have explored the risk issues and legal regulations of crowdfunding, of which the mainly focused types are patronage-based and equity-based crowdfunding. The risks in crowdfunding involve illegal fund raising, credit risk, platform operational risk, technical risk and so on. Relevant legal mechanisms are needed.

Second, some studies have investigated the motivations of fundraisers and investors to participate in crowdfunding activities. On one hand, the purpose of fundraisers taking part in crowdfunding is to attract backers to invest, obtain funds, expand awareness of their work, form connection with people, gain approval of others, and replicate the successful experience of others $[29,46]$. On the other hand, investors are motivated to support or help creators, gain or collect rewards, and become members of a community [47-50]. In addition, many scholars have also investigated the behavior of investors, such as the herding effect and the bystander effect [50-52]. In the early stage of financing, investors are more likely to follow the trend to invest in projects, and the herding effect is significant. However, in the middle stage of financing, the responsibility of investors spreads, and bystander effect becomes significant [53-55].

Third, many scholars have studied the antecedents of crowdfunding success. Mollick [1] noted that the success or failure of crowdfunding would be driven by personal networks (the number of founders' Facebook friends), underlying project quality (video, spelling errors, updates), and geography. The conclusions showed that the number of founders' Facebook friends, video, and updates are all positively related to funding success, while spelling errors reduced the chance of funding success. Geography was associated with both the type of projects and successful fundraising. Wang et al. [38] paid attention to the interaction between creators and backers. They examined the effects of comment (quantity, sentiment, and length) and reply (ratio, length, and speed) on crowdfunding success. Huang et al. [48] analyzed the factors influencing the success of crowdfunding projects from the perspective of customer value, including product value, people value, service value, image value, and monetary cost. Their study suggested that service value and image value exert significant influence on funding success, the product value and people value influence it in a certain extent, while the monetary cost influences it insignificantly. What is more, Zhou et al. [12] identified five exemplary antecedents (length, readability, tone, past experience, and past expertise) from project descriptions to study the influence of project description on funding success. Length, readability, and tone are related to the content of project description; past experience and past expertise are related to the owner of the project.

Additionally, reward-based crowdfunding is the most common type. Backers can obtain a reward via their investment. The reward can be a product, artwork, or any other reward they provide, which depends on the size of the investment [13]. There are two mechanisms for reward-based crowdfunding: "all or nothing" or "keep it all." The first one means the creators can get the funds only when the goal is reached; for the last one, the creators can keep all raised money regardless of whether the goal is reached or not [56]. In this study, we focus on Kickstarter, one of the largest reward-based crowdfunding platforms in the world, using the "all or nothing" mechanism [1].

\subsection{Information Asymmetry, Information Communication, and Signaling Theory}

Information asymmetry means that one party lacks information about the quality of another party or one party is concerned about another party's behavior tendency [33,57]. Information asymmetry is one of the key characteristics of traditional credit markets, and the increased failures of credit markets have been considered as the result of information asymmetry between lenders and borrowers. 
At the same time, research has noted that information asymmetry between creators and backers is an important factor resulting in crowdfunding failure [21]. Thus, effective information communication between the creators and the backers is necessary, and it can help reduce uncertainty and information asymmetry. Within crowdfunding, creators can spread and exchange information via crowdfunding platforms, and it is a major channel to improve the efficiency of information communication. What is more, signaling theory $[58,59]$ suggests that the behavior of entrepreneurs is related to the extent to which other parties have access to different information and depends on how they communicate and interpret information [60]. Some studies have proved that successful crowdfunding depends on credible and valuable signals provided by creators $[3,13,15,40,61]$. For example, higher Facebook "like" count can send a good word-of-mouth signal to backers [29]. Based on the signaling theory, this study will make contributions in the area by focusing on the information communication between creators and backers.

In our study, from the perspective of information communication, we explored three aspects of information description: information quantity, information quality and information attitude. Higher level of information quantity, including word count, picture count, and video count, can express more details of the project and represent signals of high quality and preparation [15,21,29]. Information quality contains readability and updates. Low readability of description shows the signals of creators' professionalism [12]. Frequent updates for projects reveal signals of quality, helping add more information to reduce the backers' confusion, and show the creators' positive attitude toward solving information asymmetry $[1,15,36,62]$. The number of comments represents the positive attitude of other backers toward the project, and a higher number of comments makes backers believe that the project has a better word-of-mouth $[29,61]$. For controls in the study, they can also deliver valuable signals. The number of projects initiated by the creator shows the creators' experience, which may positively influence the backers' decisions. More experienced creators can more easily obtain the backers' trust and are more likely to receive investment [29]. The number of projects backed by the creator represents the signal of reciprocity $[13,18]$. The funding goal shows the creator's ambition, and duration can present the creator's patience [13]. In total, based on signaling theory and information asymmetry, we focus on the perspective of information communication and discuss the influence of information description on crowdfunding success, taking the creators' experience, funding goal, duration, Facebook connections, external websites, number of rewards, start year, start month, country, and category as controls.

\section{Hypotheses Development}

\subsection{Information Quantity}

There are three types of communication modes embedded in the information description of crowdfunding projects, such as words, pictures, and videos. Thus, we identify three dimensions of information quantity: word count, picture count, and video count.

Narrative is an effective way to convey attitudes and ideas [63]. Using words to describe the crowdfunding project can convey the ideas of fundraisers to backers. Ahlers et al. [21] revealed that the amount of word has a positive effect on the crowdfunding success. Bi et al. [29], as well as Moy et al. [30], also supported the positive influence of words. Therefore, increasing the word count within the range of optimal number of words is beneficial to crowdfunding. Thus, a higher word count within optimal quantity will help describe the project in more detail, which can allow backers to more easily understand the project information. However, too much information can increase the burden of understanding, which also further complicates project evaluation [26,64]. In this situation, the demand for processing too much information may discourage backers from supporting crowdfunding projects [26]. Therefore, excess information will have negative effects on crowdfunding success [30]. Hence, we propose the following hypotheses: 
Hypothesis 1a. The number of words in project description is associated with crowdfunding success in an inverted-U shape such that excess words in project description will negatively affect the crowdfunding success.

Pictures are more effective storytelling tools than word-only information $[65,66]$. Pictures can convey more details of projects and bring backers inside your story. Huang et al. [48] analyzed the factors of crowdfunding success using Customer Value Theory, whose study showed that image count in the project introduction positively influences crowdfunding success. Many empirical studies have also found that the number of pictures in the project description is associated with crowdfunding success [16,27]. Adding more pictures in the project description can exert more powerful persuasion for backers and increase the likelihood of crowdfunding success.

Hypothesis $\mathbf{1 b}$. The number of pictures in project description is positively associated with crowdfunding success.

Videos consist of visual (image and animation), verbal, and audio elements. Videos are very useful for promoting products and services and stimulating consumption [67]. Videos usually contain more detailed information, requiring less imagination. Contrary to the text-only situation, there is no need to use your imagination to understand all the information in videos, because videos can provide complete details [15]. According to the literature on crowdfunding, Mollick [1] revealed that having video in the project description is related to crowdfunding success. Video has a positive effect on success [1], and there are many empirical studies that confirmed the positive effect of video on crowdfunding success $[1,16,27,29,40]$.

Hypothesis 1c. The number of videos in project description is positively associated with crowdfunding success.

\subsection{Information Quality}

Readability refers to the easiness of text understanding [68], which can be measured by Gunning Fog Index [12,69] or other tools [70]. The readability variable has been widely used in previous studies [70,71]. In crowdfunding platforms, to provide information effectively, the project description should be easy to understand without possible puzzles. The poor readability of project description would lead to information asymmetry, and if the description of project is easy to understand, its meaning will spread to more potential backers. Thus, backers will have a greater possibility to support the project [12].

Hypothesis 2a. The readability of project description is positively associated with crowdfunding success.

In a crowdfunding website, the project has its own page to present information including the introduction, goal, location and fundraiser. Most crowdfunding platforms have the function of update, which facilitates communication between creators and backers [15,52]. Project updates can present the development of project timely. What is more, according to the literature on crowdfunding, scholars also note that frequent updates can show the positive attitude of creators and represent signals of information quality, which can reduce information asymmetry and increase trust in order to make backers support it $[1,36,62]$. Mollick [1] demonstrated that frequent updates during funding have positive influence on success. Prior researchers also confirmed the positive effect of updates [15,52].

Hypothesis $\mathbf{2 b}$. The update frequency of project description is positively associated with crowdfunding success.

\subsection{Information Attitude}

Online comments have become the most effective marketing tools for enterprises. Comments show the reviews, opinions, and shared experiences of people, which matter to the potential consumers, because most people are affected by the word-of-mouth and people usually depend on the comments 
to make purchase decisions [72,73]. For example, people usually evaluate the product or service using the number of comments and choose to purchase the products with more comments [73,74]. On crowdfunding platforms, comments consist of backers' comments and creators' replies. On one hand, backers share information about the project by posting comments. On the other hand, comments facilitate communication between backers and creators. Potential backers can ask questions through comments, and creators can reply with more personalized information. These comments can be viewed by other potential backers. Thus, more comments can convey more information to potential bakers and they can gain an in-depth understanding of the project through the comments. This also illustrates that more comments signal high quality of project. What is more, scholars also confirmed the positive effect of comments on crowdfunding success $[1,29,33,38,40,61]$. Hence, we hypothesize the following:

Hypothesis 3. The number of comments of project description is positively associated with crowdfunding success.

\subsection{The Moderating Effect of Comment}

Online comment is one of the main ways of electronic word-of-mouth communication, which has a more and more important role in decision making of consumers [75,76]. Consumers usually express their own opinions and experiences of products or services through comments. What is more, more and more people browse comments before purchasing. If most of the comments are positive, people will purchase it directly. For crowdfunding, backers usually browse comments of projects to learn more details, and this can reduce information asymmetry and uncertainty [77,78]. Under these circumstances, the influence of project description on crowdfunding success may be reduced. Thus, the following hypotheses are posited:

Hypothesis 4a. The number of comments moderates the curvilinear relationship between the number of words and crowdfunding success in an inverted-U shape, such that this relationship is stronger for projects with fewer comments than that with more comments.

Hypothesis $\mathbf{4 b}$. The number of comments negatively moderates the relationship between the number of pictures and crowdfunding success, such that the positive relationship is stronger when the number of comments is low.

Hypothesis 4c. The number of comments negatively moderates the relationship between the number of videos and crowdfunding success, such that the positive relationship is stronger when the number of comments is low.

Based on the above hypotheses, our research model is shown as Figure 1. We consider three dimensions of information description, including information quantity, information quality, and information attitude. The information quantity is reflected as word count, picture count, and video count. Information quality includes readability and update. Information attitude contains comment. Since projects' characteristics (funding goal, duration, start year, start month, number of rewards, country and category) and creators' characteristics (experience as creator, experience as backer, external websites, and Facebook connections) have been identified as antecedents of crowdfunding success in previous researches $[1,9,12,13,22,29,64,79,80]$, we treat them as control variables. What is more, we consider comments as both an antecedent influencer and a moderator to test. 


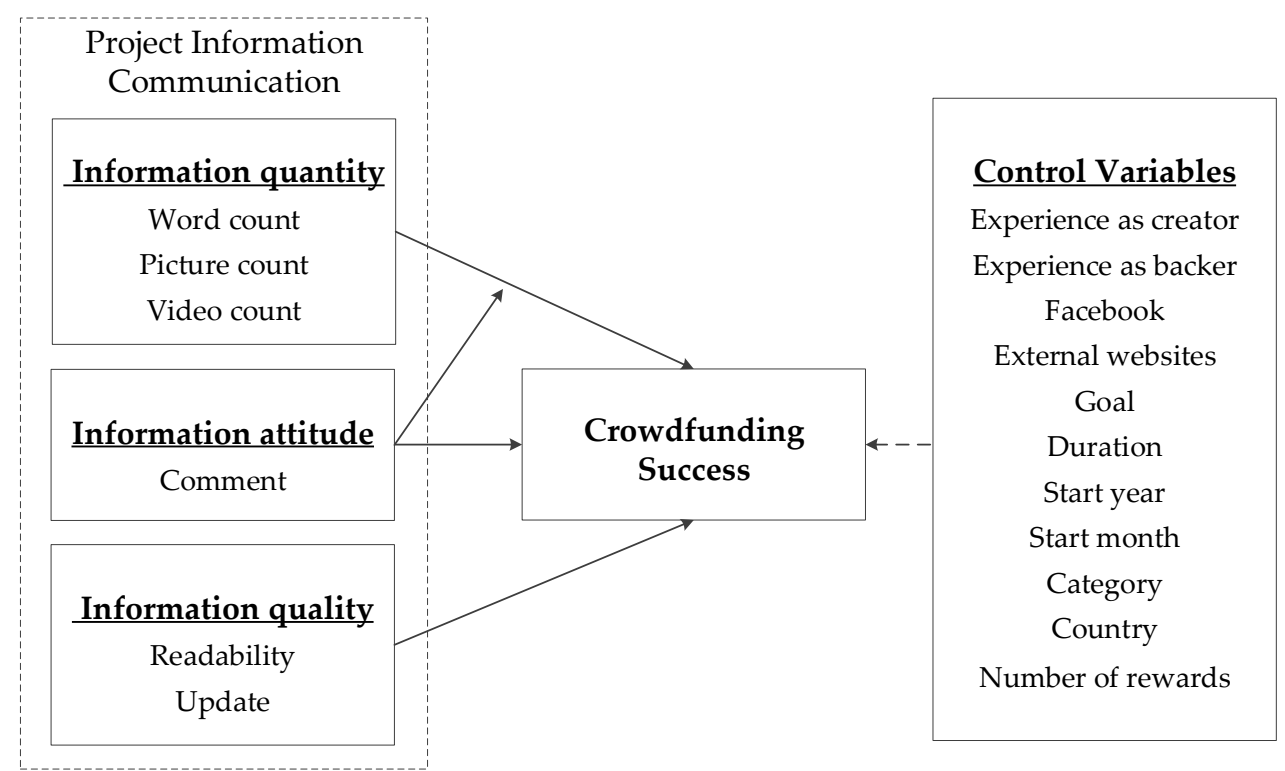

Figure 1. Theoretical model.

\section{Methodology}

\subsection{Mathematical Model}

To test if the hypotheses are true, we use the following mathematical model:

Crowdfunding Success $=\beta 0+\beta 1$ Word count $+\beta 2$ Word count $^{2}+\beta 3$ Picture count $+\beta 4$

Video count $+\beta 5$ Readability $+\beta 6$ Update $+\beta 7$ Comment $+\beta 8$ Controls $+\varepsilon$,

where the controls are experience as creator, experience as backer, Facebook, external websites, goal, duration, start year, start month, category, country, number of rewards.

\subsection{Measurement}

\subsubsection{Dependent Variables}

Our dependent variable, crowdfunding success, refers to whether the funding goal was met [24]. Kickstarter uses the "all-or-nothing" mechanism. The funding goal is set at the beginning of the campaign. If the funding goal is not met during the duration of the campaign, the backers will be refunded, and the creators will not receive any funds [1]. Therefore, achieving the funding goal means crowdfunding success, which is one of the indicators of crowdfunding performance $[5,21,81]$. In line with other crowdfunding studies [13,15,82], we also use crowdfunding success as the dependent variable. If the project is funded successfully (funds raised are greater than or equal to the funding goal), the value of crowdfunding success is 1 , otherwise it is 0 (funds raised are less than funding goal).

\subsubsection{Independent Variables}

\section{Information Quantity}

In this study, according to the description types, we identify three dimensions of information quantity, including word count, picture count, and video count. Pictures and videos are more powerful tools than words in communicating information, since they can directly present detailed information $[27,83]$. Furthermore, using multiple modes to describe information may generate a higher level of communication efficiency compared with using separate text or image information [15]. Hence, in our study, word count refers to the total number of words in project description $[12,15,24,30,82]$. 
Picture count reflects the total number of pictures in project description [12,27,38]. Video count represents the total number of videos in the project description $[12,15,27,38]$.

\section{Information Quality}

In the crowdfunding context, information quality can be measured by readability and update. Following the previous literature, we use the Gunning Fog Index to measure the readability of information description [12,69]. The Gunning Fog Index was developed by Robert Gunning in 1952 and is a well-known formula for measuring readability [69]. The Fog Index captures text complexity as a function of words per sentence and syllables per word. We measure complex words by words with greater than or equal to eight letters. It is calculated with the following algorithm [69]:

$$
\text { The Gunning Fog Index }=0.4\left[\left(\frac{\text { words }}{\text { sentences }}\right)+100\left(\frac{\text { complex words }}{\text { words }}\right)\right] \text {. }
$$

Commonly, in the case where the Fog Index is between 12 and 14, the reading ease is ideal. If the Fog Index is between 14 and 18, the reading is difficult. If the Fog Index that is larger than 18, the text is unreadable. If the Fog Index is smaller than 12 and larger than 10, it means the reading ease of the information is acceptable [69]. Therefore, the higher the Fog Index, the lower the readability. Therefore, readability uses the negative value of the Fog Index [12].

$$
\text { Readability }=-0.4\left[\left(\frac{\text { words }}{\text { sentences }}\right)+100\left(\frac{\text { complex words }}{\text { words }}\right)\right]
$$

What is more, since that the update is not available for creators when the campaign is ended, we measure the information update using the number of updates between the launched time and the ended time of the project $[52,61]$.

\section{Information Attitude}

Comments reflect the backers' positive or negative attitudes toward the project. On Kickstarter, only backers can post their comments about the project on the website. And the visitors and potential backers can browse the comments. We measure the comment variable using the total number of comments about the project $[40,61]$.

\subsubsection{Control Variables}

To rule out the possible effects of other antecedents that can affect crowdfunding performance, we treat them as control variables, including experience as creator, experience as backer, Facebook, external websites, funding goal, duration, start year, start month, category, country, and number of rewards. First, we control for creators' characteristics. Experience as a creator is measured by the number of past projects initiated by the creator, and we measure experience as backer using the number of past projects backed by the creator $[12,13,38]$. Facebook is a dummy variable that is coded as 1 if Facebook of creator is connected, and 0 otherwise [12]. External websites are measured by the number of the links of external websites in creator page. Second, we also control for projects' characteristics. Funding goal refers to the target amount raised by creators. Since the funding goal is easier to meet when it is lower, we control for the funding goal $[4,26,29,40,64]$. Furthermore, duration represents the length of time for funding. Only during the time limit, backers can invest. In Kickstarter, the length of the time allowed for funding is 1-60 days. Since successful projects tend to be shorter in duration, many researchers control for the duration $[4,26,29,64,82]$. In this study, duration is measured by the number of days during the fundraising. Start year and start month refers to the year and month when the project launched respectively, and they are both measured by dummy variables [12,33,79]. In addition, there are 15 categories in Kickstarter platform. Thus, we use 14 dummy variables to measure the category, and "theater" is treated as the reference category $[2,79]$. Country is a dummy variable that 
reflects whether the project is located in the United States. If the project location is in the United States, the value is 1 ; otherwise, it is $0[9,22,80]$. What is more, we control rewards measured by the number of reward levels offered in the campaign [33]. All variables and their measures are shown in Table 1.

Table 1. Variables and their measures.

\begin{tabular}{|c|c|}
\hline Variables & Measures \\
\hline \multicolumn{2}{|l|}{ Dependent Variable } \\
\hline Crowdfunding Success & The value of successful funding is 1 , otherwise it is 0 \\
\hline \multicolumn{2}{|l|}{ Independent Variables } \\
\hline Word count & Number of words in the project description \\
\hline Picture count & Number of pictures in the project description \\
\hline Video count & Number of videos in the project description \\
\hline Readability & The negative value of Gunning Fog Index \\
\hline Update & Number of updates between the launched time and the ended time crowdfunding \\
\hline Comment & Number of comments about the project \\
\hline \multicolumn{2}{|l|}{ Control Variables } \\
\hline Experience as creator & Number of projects initiated by the creator \\
\hline Experience as backer & Number of projects backed by the creator \\
\hline Facebook & If Facebook of creator is connected, the value is 1 , otherwise it is 0 \\
\hline External websites & Number of the links of external websites \\
\hline Goal (USD) & Target amount of the funding \\
\hline Duration & Number of days during the fundraising \\
\hline Start year & The year when the project launched \\
\hline Start month & The month when the project launched \\
\hline Category & Category of project; 15 categories measured by 14 dummy variables \\
\hline \multirow[t]{2}{*}{ Country } & If project location is in the US, the value is 1 , otherwise it is 0 \\
\hline & United States; 0 otherwise \\
\hline Number of rewards & Number of reward levels offered \\
\hline
\end{tabular}

\subsection{Data Collection}

The data of this study were collected from Kickstarter using Python which is a software that can crawl the desired information from the website, and part of the data were collected manually. Kickstarter is one of most popular and largest crowdfunding websites in the world. It was launched in 2009. So far, it has more than sixteen million backers, and about five million of them are repeat backers. At present, more than 162,000 projects have been successfully funded, and more than four billion dollars have been raised (Kickstarter, 2019). What is more, the majority of researches on crowdfunding collect data on Kickstarter $[1,2,4,13]$. Therefore, we also choose the Kickstarter website as the data collecting source. This enables us to make comparisons between the results of our study and that of previous researches, helping make our results more reliable and meaningful.

We collected the data of the latest projects spanning from September 2018 to May 2019. There are five types of statuses of the projects: active projects, successfully funded projects, failed projects, canceled projects and suspended projects. Active projects mean the fundraising is ongoing at the date of the searching time. The successfully funded projects represent those projects of which the funding goals have been reached. On the contrary, the failed projects demonstrate that the raised money of these projects is less than the goal at the end of campaign. The fourth type is canceled projects; this happens when the creator canceled the project before the goal had been reached and ends the duration. The last one is suspended projects. In this case, the Kickstarter website suspends the campaign because of cheating or other reasons. Thus, to study crowdfunding success or failure, we excluded projects that were ongoing (145 projects) at the date of the data collection (13 May 2019). Projects were canceled by different reasons. When creators think that they will be unable to follow through the project before goal is reached, they can cancel it. It is possible that creators want to improve the project and launch a new project later, and projects were suspended due to fraud or 
violation of Kickstarter's rules. Thus, canceled projects and suspended projects are not typical failed or unsuccessful projects. We also removed the canceled projects and the suspended projects (2083 projects) from them $[5,12,22,23,30,33,84]$. What is more, according to the previous study [1], we also removed projects with goals less than $\$ 100$ USD (309 projects) or more than $\$ 1,000,000$ USD (four projects), which were extreme values of goals and showed non-serious efforts to raise funds [1]. The projects with extreme values may have different characteristics from the majority of projects. Furthermore, we also removed projects with goals less than $\$ 5000$ USD $(10,264$ projects) $[1,85,86]$. This is because family and friends can provide funds to help these small projects achieve crowdfunding success. The resulting dataset contains 7207 projects across all 15 funding categories. Table 2 shows the process of data selecting. Table 3 shows the project category distribution of the sample.

Table 2. Sample selection process.

\begin{tabular}{lc}
\hline \multicolumn{1}{c}{ Sample } & Number \\
\hline All projects crawled & 20,012 \\
Ongoing projects & 145 \\
Canceled and Suspended projects & 2083 \\
Projects with goal less than 100 dollars & 309 \\
Projects with goal more than 1,000,000 dollars & 4 \\
Projects with goal less than 5000 dollars & 10,264 \\
Total sample projects & 7207 \\
\hline
\end{tabular}

Table 3. Project category distribution of the sample.

\begin{tabular}{lcccccccc}
\hline Category & Art & Comics & Crafts & Dance & Design & Fashion & Film \&Video & Food \\
\hline Number & 616 & 444 & 91 & 53 & 935 & 470 & 826 & 517 \\
\hline Category & Games & Journalism & Music & Photography & Publishing & Technology & Theater & \\
\hline Number & 609 & 184 & 788 & 143 & 665 & 703 & 163 & \\
\hline
\end{tabular}

\section{Results}

\subsection{Descriptive Statistical Analysis}

The results of descriptive statistical analysis are showed in Table 4, listing the means, standard deviations and the correlated relationships among variables. As shown in Table 4, the correlation coefficients are all between -0.194 and 0.427 . The correlated relationship is not high. In addition, Table 4 also shows that the value of VIF for each independent variable, which is far less than 10 . Therefore, there is no multicollinearity problem between variables.

\subsection{Binary Logistic Regression Analysis}

Since the dependent variable (crowdfunding success) is a dichotomous variable which takes a value of either 1 or 0 , we test the hypotheses using the binary logistic regression. To reduce the problem of multicollinearity between variables, we standardized the independent variables, control variables and the variables included in interaction terms [87]. But the dummy variables, including Facebook, country, start year, start month and category are not standardized. We have established nine models. Model 1 only consists of the control variables and the dependent variable. We add the independent variables to Models $2-7$ one by one in order to test the hypotheses individually. Model 8 presents the full model including main effects. Furthermore, we add the moderator to Model 9 including all variables. The analysis results are presented in Table 5. 
Table 4. Descriptive statistics and correlations.

\begin{tabular}{|c|c|c|c|c|c|c|c|c|c|c|c|c|c|c|c|c|c|c|}
\hline Variables & Mean & SD & VIF & 1 & 2 & 3 & 4 & 5 & 6 & 7 & 8 & 9 & 10 & 11 & 12 & 13 & 14 & 15 \\
\hline 1.Goal & $19,547.26$ & $41,240.32$ & 1.078 & 1 & & & & & & & & & & & & & & \\
\hline 2.Duration & 32.89 & 9.787 & 1.095 & $\underset{* *}{0.087}$ & 1 & & & & & & & & & & & & & \\
\hline 3.Experience_creator & 2.27 & 3.447 & 1.345 & 0.007 & $\underset{* *}{-0.143}$ & 1 & & & & & & & & & & & & \\
\hline 4.Experience_backer & 10.61 & 31.265 & 1.373 & -0.008 & $\underset{* *}{-0.120}$ & $\underset{* *}{0.427}$ & 1 & & & & & & & & & & & \\
\hline 5. Facebook & 0.43 & 0.495 & 1.082 & $\underset{* *}{-0.044}$ & -0.021 & $\underset{* *}{0.112}$ & $\underset{* *}{0.148}$ & 1 & & & & & & & & & & \\
\hline 6.External websites & 1.84 & 1.555 & 1.113 & 0.016 & $\underset{* *}{-0.077}$ & $\underset{* *}{0.136}$ & $\underset{* *}{0.126}$ & 0.138 & 1 & & & & & & & & & \\
\hline 7. Country & 0.67 & 0.471 & 1.082 & -0.002 & $\underset{* *}{-0.041}$ & $\begin{array}{c}0.065 \\
* *\end{array}$ & $\begin{array}{c}0.075 \\
* *\end{array}$ & $\begin{array}{c}0.051 \\
* *\end{array}$ & -0.003 & 1 & & & & & & & & \\
\hline 8.Rewards & 6.12 & 7.872 & 1.279 & 0.008 & $\begin{array}{c}-0.028 \\
*\end{array}$ & 0.003 & -0.007 & 0.014 & $\underset{* *}{0.071}$ & $\underset{* *}{0.064}$ & 1 & & & & & & & \\
\hline 9. Word count & 1024.76 & 709.95 & 2.348 & $\underset{* *}{0.060}$ & $\underset{* *}{-0.080}$ & 0.120 & $\underset{* *}{0.139}$ & 0.018 & $\underset{* *}{0.126}$ & $\underset{* *}{-0.082}$ & $\underset{* *}{0.075}$ & 1 & & & & & & \\
\hline 10.Picture count & 18.38 & 19.126 & 1.948 & $\underset{* *}{0.049}$ & 0.013 & $\begin{array}{c}0.125 \\
* *\end{array}$ & $\begin{array}{c}0.130 \\
* *\end{array}$ & $\begin{array}{c}-0.030 \\
* *\end{array}$ & $\begin{array}{c}0.089 \\
* *\end{array}$ & $\underset{* *}{-0.161}$ & $\begin{array}{c}0.049 \\
* *\end{array}$ & $\begin{array}{c}0.408 \\
* *\end{array}$ & 1 & & & & & \\
\hline 11.Video count & 0.37 & 1.088 & 1.155 & $\underset{*}{0.026}$ & $\underset{* *}{0.045}$ & $\underset{* *}{-0.034}$ & $\underset{* *}{-0.041}$ & $\underset{* *}{-0.035}$ & 0.008 & $\underset{* *}{-0.076}$ & $-\underset{* *}{-0.038}$ & $\underset{* *}{0.157}$ & $\begin{array}{c}0.286 \\
* *\end{array}$ & 1 & & & & \\
\hline 12. Comment & 106.18 & 756.74 & 1.142 & $\underset{* *}{0.212}$ & 0.004 & 0.122 & $\underset{* *}{0.073}$ & -0.021 & 0.022 & -0.002 & -0.013 & $\underset{* *}{0.069}$ & 0.182 & $\begin{array}{c}0.033 \\
* *\end{array}$ & 1 & & & \\
\hline 13. Readability & -18.86 & 3.12 & 1.033 & -0.001 & 0.017 & -0.011 & -0.009 & $\begin{array}{c}0.036 \\
* * \\
\end{array}$ & -0.032 & 0.053 & $\underset{*}{-0.024}$ & -0.066 & 0.004 & $\begin{array}{c}0.027 \\
*\end{array}$ & -0.001 & 1 & & \\
\hline 14.Update & 8.42 & 9.042 & 1.396 & $\underset{* *}{0.034}$ & $\begin{array}{c}-0.025 \\
*\end{array}$ & $\underset{* *}{0.197}$ & $\underset{* *}{0.208}$ & $\begin{array}{c}0.083 \\
* *\end{array}$ & $\begin{array}{c}0.158 \\
* *\end{array}$ & 0.004 & $\begin{array}{c}0.092 \\
* *\end{array}$ & $\underset{* *}{0.254}$ & $\underset{* *}{0.321}$ & $\underset{* *}{0.088}$ & $\underset{* *}{0.209}$ & -0.001 & 1 & \\
\hline 15.Success & 0.88 & 0.319 & DV & -0.161 & $\underset{* *}{-0.194}$ & 0.104 & 0.107 & $\underset{* *}{0.035}$ & $\underset{* *}{0.145}$ & $\underset{* *}{0.048}$ & $\underset{* *}{0.162}$ & 0.165 & 0.212 & $\underset{* *}{0.048}$ & $\underset{* *}{0.050}$ & $-{ }_{* *}^{0.033}$ & $\begin{array}{c}0.293 \\
* *\end{array}$ & 1 \\
\hline
\end{tabular}


Table 5. Binary logistic regression analysis results on crowdfunding success.

\begin{tabular}{|c|c|c|c|c|c|c|c|c|c|}
\hline \multirow{2}{*}{ Variables } & Model 1 & Model 2 & Model 3 & Model 4 & Model 5 & Model 6 & Model 7 & Model 8 & Model 9 \\
\hline & $\begin{array}{c}\text { Controls } \\
\text { Only }\end{array}$ & Word Count & Picture Count & Video Count & Comment & Readability & Update & Main Effects & $\begin{array}{l}\text { Comment } \\
\text { Moderator }\end{array}$ \\
\hline \multicolumn{10}{|l|}{ Controls } \\
\hline Goal & $\begin{array}{c}-0.036^{* * *} \\
(0.003)\end{array}$ & $\begin{array}{c}-0.037^{* * *} \\
(0.003)\end{array}$ & $\begin{array}{c}-0.038^{* * *} \\
(0.003)\end{array}$ & $\begin{array}{c}-0.036^{* * *} \\
(0.003)\end{array}$ & $\begin{array}{c}-0.039 * * * \\
(0.003)\end{array}$ & $\begin{array}{c}-0.036^{* * *} \\
(0.003)\end{array}$ & $\begin{array}{c}-0.038^{* * *} \\
(0.003)\end{array}$ & $\begin{array}{c}-0.041^{* * *} \\
(0.003)\end{array}$ & $\begin{array}{c}-0.042^{* * *} \\
(0.003)\end{array}$ \\
\hline Duration & $\begin{array}{c}-0.056^{* * *} \\
(0.003)\end{array}$ & $\begin{array}{c}-0.052 * * * \\
(0.003)\end{array}$ & $\begin{array}{c}-0.055^{* * *} \\
(0.003)\end{array}$ & $\begin{array}{c}-0.056^{* * *} \\
(0.003)\end{array}$ & $\begin{array}{c}-0.056^{* * *} \\
(0.003)\end{array}$ & $\begin{array}{c}-0.056^{* * *} \\
(0.003)\end{array}$ & $\begin{array}{c}-0.056^{* * *} \\
(0.003)\end{array}$ & $\begin{array}{c}-0.053^{* * *} \\
(0.003)\end{array}$ & $\begin{array}{c}-0.053^{* * *} \\
(0.003)\end{array}$ \\
\hline Experience as creator & $\begin{array}{c}0.010^{* *} \\
(0.003)\end{array}$ & $\begin{array}{c}0.012 \text { ** } \\
(0.003)\end{array}$ & $\begin{array}{c}0.009 * * \\
(0.003)\end{array}$ & $\begin{array}{c}0.011^{* *} \\
(0.003)\end{array}$ & $\begin{array}{c}0.009 * * \\
(0.003)\end{array}$ & $\begin{array}{c}0.010^{* *} \\
(0.003)\end{array}$ & $\begin{array}{l}0.007^{*} \\
(0.003)\end{array}$ & $\begin{array}{l}0.007^{*} \\
(0.003)\end{array}$ & $\begin{array}{l}0.008^{*} \\
(0.003)\end{array}$ \\
\hline Experience as backer & $\begin{array}{c}0.015^{* * *} \\
(0.003)\end{array}$ & $\begin{array}{c}0.012 * * \\
(0.003)\end{array}$ & $\begin{array}{c}0.011 * * \\
(0.003)\end{array}$ & $\begin{array}{c}0.015^{* * *} \\
(0.003)\end{array}$ & $\begin{array}{c}0.015^{* * *} \\
(0.003)\end{array}$ & $\begin{array}{c}0.015^{* * *} \\
(0.003)\end{array}$ & $\begin{array}{l}0.010^{*} \\
(0.003)\end{array}$ & $\begin{array}{l}0.008^{*} \\
(0.003)\end{array}$ & $\begin{array}{l}0.007^{+} \\
(0.003)\end{array}$ \\
\hline Facebook & $\begin{array}{c}-0.012^{+} \\
(0.006)\end{array}$ & $\begin{array}{c}-0.013 * \\
(0.006)\end{array}$ & $\begin{array}{c}-0.012^{+} \\
(0.006)\end{array}$ & $\begin{array}{c}-0.012^{+} \\
(0.006)\end{array}$ & $\begin{array}{c}-0.011^{+} \\
(0.006)\end{array}$ & $\begin{array}{c}-0.011^{+} \\
(0.006)\end{array}$ & $\begin{array}{c}-0.015 * \\
(0.006)\end{array}$ & $\begin{array}{c}-0.013 * \\
(0.006)\end{array}$ & $\begin{array}{c}-0.014{ }^{*} \\
(0.006)\end{array}$ \\
\hline External websites & $\begin{array}{c}0.022 * * * \\
(0.003)\end{array}$ & $\begin{array}{c}0.015^{* * *} \\
(0.003)\end{array}$ & $\begin{array}{c}0.017^{* * *} \\
(0.003)\end{array}$ & $\begin{array}{c}0.021^{* * *} \\
(0.003)\end{array}$ & $\begin{array}{c}0.021^{* * *} \\
(0.003)\end{array}$ & $\begin{array}{c}0.021^{* * *} \\
(0.003)\end{array}$ & $\begin{array}{c}0.017^{* * *} \\
(0.003)\end{array}$ & $\begin{array}{c}0.011^{* * *} \\
(0.003)\end{array}$ & $\begin{array}{c}0.011^{* * *} \\
(0.003)\end{array}$ \\
\hline Country & $\begin{array}{l}0.017^{*} \\
(0.007)\end{array}$ & $\begin{array}{c}0.024^{* * *} \\
(0.006)\end{array}$ & $\begin{array}{c}0.026^{* * *} \\
(0.006)\end{array}$ & $\begin{array}{c}0.017 * * \\
(0.007)\end{array}$ & $\begin{array}{l}0.016^{*} \\
(0.007)\end{array}$ & $\begin{array}{c}0.018^{* *} \\
(0.007)\end{array}$ & $\begin{array}{l}0.016^{*} \\
(0.006)\end{array}$ & $\begin{array}{c}0.028^{* * *} \\
(0.006)\end{array}$ & $\begin{array}{c}0.028^{* * *} \\
(0.006)\end{array}$ \\
\hline Number of rewards & $\begin{array}{c}0.032 * * * \\
(0.003)\end{array}$ & $\begin{array}{c}0.027^{* * *} \\
(0.003)\end{array}$ & $\begin{array}{c}0.026^{* * *} \\
(0.003)\end{array}$ & $\begin{array}{c}0.032 * * * \\
(0.003)\end{array}$ & $\begin{array}{c}0.032 * * * \\
(0.003)\end{array}$ & $\begin{array}{c}0.032^{* * *} \\
(0.003)\end{array}$ & $\begin{array}{c}0.027 * * * \\
(0.003)\end{array}$ & $\begin{array}{c}0.021 * * * \\
(0.003)\end{array}$ & $\begin{array}{c}0.021 * * * \\
(0.003)\end{array}$ \\
\hline Category & Yes & Yes & Yes & Yes & Yes & Yes & Yes & Yes & Yes \\
\hline Start year & Yes & Yes & Yes & Yes & Yes & Yes & Yes & Yes & Yes \\
\hline \multicolumn{10}{|l|}{ Main effects } \\
\hline Word count & & $\begin{array}{c}0.064^{* * *} \\
(0.004)\end{array}$ & & & & & & $\begin{array}{c}0.039 * * * \\
(0.002)\end{array}$ & $\begin{array}{c}0.038^{* * *} \\
(0.004)\end{array}$ \\
\hline Word count ${ }^{2}$ & & $\begin{array}{c}-0.017^{* * *} \\
(0.002)\end{array}$ & & & & & & $\begin{array}{c}-0.014^{* * *} \\
(0.002)\end{array}$ & $\begin{array}{c}-0.014^{* * * *} \\
(0.002)\end{array}$ \\
\hline Picture count & & & $\begin{array}{c}0.059 * * * \\
(0.004)\end{array}$ & & & & & $\begin{array}{c}0.038 * * * \\
(0.004)\end{array}$ & $\begin{array}{c}0.040 * * * \\
(0.004)\end{array}$ \\
\hline Video count & & & & $\begin{array}{c}0.013 * * * \\
(0.003)\end{array}$ & & & & $\begin{array}{c}0.001 \\
(0.003)\end{array}$ & $\begin{array}{c}0.001 \\
(0.003)\end{array}$ \\
\hline Comment & & & & & $\begin{array}{c}0.017^{* * *} \\
(0.003)\end{array}$ & & & $\begin{array}{l}0.007^{*} \\
(0.003)\end{array}$ & $\begin{array}{c}0.027^{* * *} \\
(0.006)\end{array}$ \\
\hline Readability & & & & & & $\begin{array}{c}-0.011^{* * *} \\
(0.003)\end{array}$ & & $\begin{array}{c}-0.009 * * \\
(0.003)\end{array}$ & $\begin{array}{c}-0.009^{* *} \\
(0.003)\end{array}$ \\
\hline Update & & & & & & & $\begin{array}{c}0.055^{* * *} \\
(0.003)\end{array}$ & $\begin{array}{c}0.042^{* * *} \\
(0.003)\end{array}$ & $\begin{array}{c}0.041^{* * *} \\
(0.003)\end{array}$ \\
\hline
\end{tabular}


Table 5. Cont

\begin{tabular}{|c|c|c|c|c|c|c|c|c|c|}
\hline \multirow{2}{*}{ Variables } & Model 1 & Model 2 & Model 3 & Model 4 & Model 5 & Model 6 & Model 7 & Model 8 & Model 9 \\
\hline & $\begin{array}{c}\text { Controls } \\
\text { Only }\end{array}$ & Word Count & Picture Count & Video Count & Comment & Readability & Update & Main Effects & $\begin{array}{l}\text { Comment } \\
\text { Moderator }\end{array}$ \\
\hline Comment $\times$ Word_count & & & & & & & & & $\begin{array}{l}-0.007 \\
(0.005)\end{array}$ \\
\hline Comment $\times$ Word_count ${ }^{2}$ & & & & & & & & & $\begin{array}{c}0.002 \\
(0.001)\end{array}$ \\
\hline Comment $\times$ Picture count & & & & & & & & & $\begin{array}{c}-0.014^{* * *} \\
(0.003)\end{array}$ \\
\hline Comment $\times$ Video count & & & & & & & & & $\begin{array}{l}-0.002 \\
(0.005)\end{array}$ \\
\hline $\begin{array}{c}\text { Constant } \\
\text { Model summary }\end{array}$ & $0.879 * * *$ & $0.880^{* * *}$ & $0.899^{* * *}$ & $0.884^{* * *}$ & $0.882^{* * *}$ & $0.871^{* * *}$ & $0.925^{* * *}$ & $0.926^{* * *}$ & $0.931^{* * *}$ \\
\hline Adjusted $\mathrm{R}^{2}$ & 0.371 & 0.391 & 0.393 & 0.373 & 0.374 & 0.372 & 0.395 & 0.417 & 0.418 \\
\hline F statistic & $138.303^{* * *}$ & $141.302^{* * *}$ & $146.836^{* * *}$ & $134.896^{* * *}$ & $135.505^{* * *}$ & $134.590^{* * *}$ & $148.028^{* * *}$ & $136.707^{* * *}$ & $124.473^{* * *}$ \\
\hline
\end{tabular}


H1a investigates the inverted-U effects of word count on crowdfunding success. Model 8 shows that the word count was associated with crowdfunding success in an inverted-U shape $\left(b_{\text {linear }}=0.039, p<0.001 ; b_{\text {square }}=-0.014, p<0.001\right)$. Thus, H1a is supported. And the curvilinear effect of word count is shown in Figure 2. The optimal value of word count in Figure 2 is 1.39. Since the word count is standardized and the actual value of the original variable is 2013 . As shown in Table 5, the picture count $(b=0.038, p<0.001)$, update $(b=0.042, p<0.001)$ and comment $(b=0.007, p<0.05)$ are all significantly and positively related to crowdfunding success, supporting the Hypothesis $1 b$, Hypothesis $2 b$ and Hypothesis 3 respectively. As shown in Model 4, the video count $(b=0.013, p<0.001)$ positively affects crowdfunding success. However, when considered with other variables together, the effect of the video count is not significant and suppressed by other variables in Model 8. H1c is not supported. What is more, we find that readability $(b=-0.009, p<0.01)$ affects crowdfunding success negatively. This is contrary to the hypothesis. Therefore, the Hypothesis $2 \mathrm{a}$ is not supported.

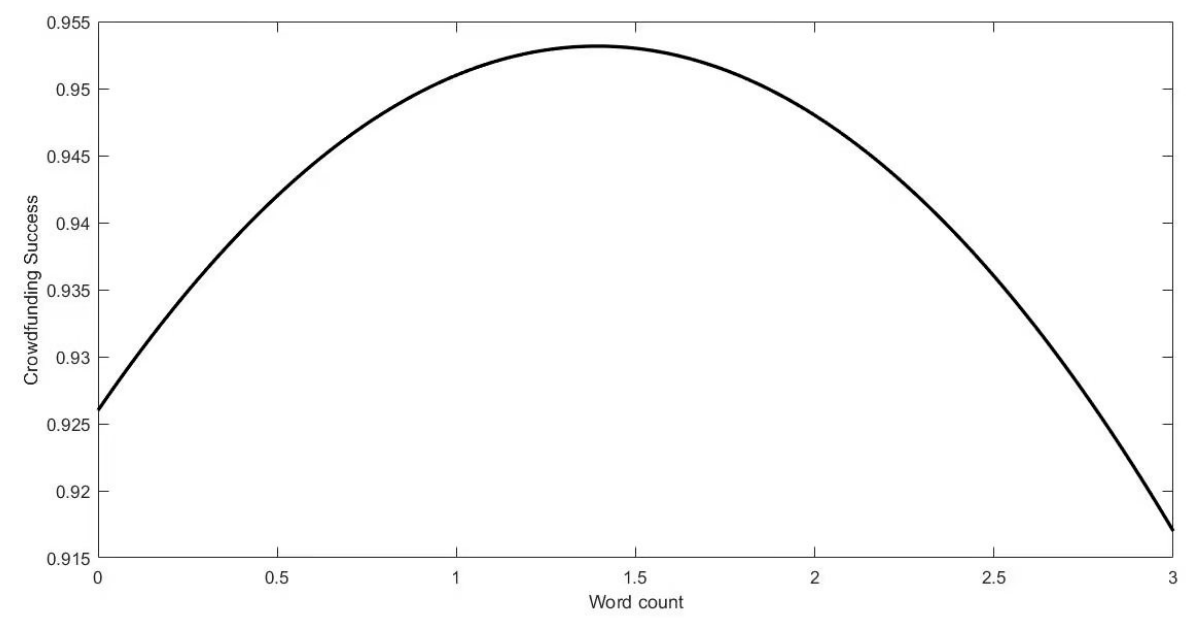

Figure 2. Effect of word count on crowdfunding success.

The moderating effects examined in Model 9 indicate that comment $(b=-0.014, p<0.001)$ negatively moderates the relationship between the picture count and crowdfunding success, supporting Hypothesis $4 \mathrm{~b}$. This means that the comments of projects reduce the importance of picture count for crowdfunding success. Following Aiken and West (1991), we plotted this moderating effect. Figure 3 illustrates that the relationship between picture count and crowdfunding success is strongly positive when comment is low (1 SD below the mean), but it is flat when comment count is high (1 SD above the mean). In other words, with comment count increasing, picture count has reduced effects on crowdfunding success. However, comment count has no significant moderating effects on the relationship between word count $\left(b_{\text {linear }}=-0.007, n s ; b_{\text {square }}=0.002, n s\right)$, video count $(b=-0.002, n s)$ and crowdfunding success. Therefore, Hypothesis $4 \mathrm{a}$ and Hypothesis $4 \mathrm{c}$ are not supported. 


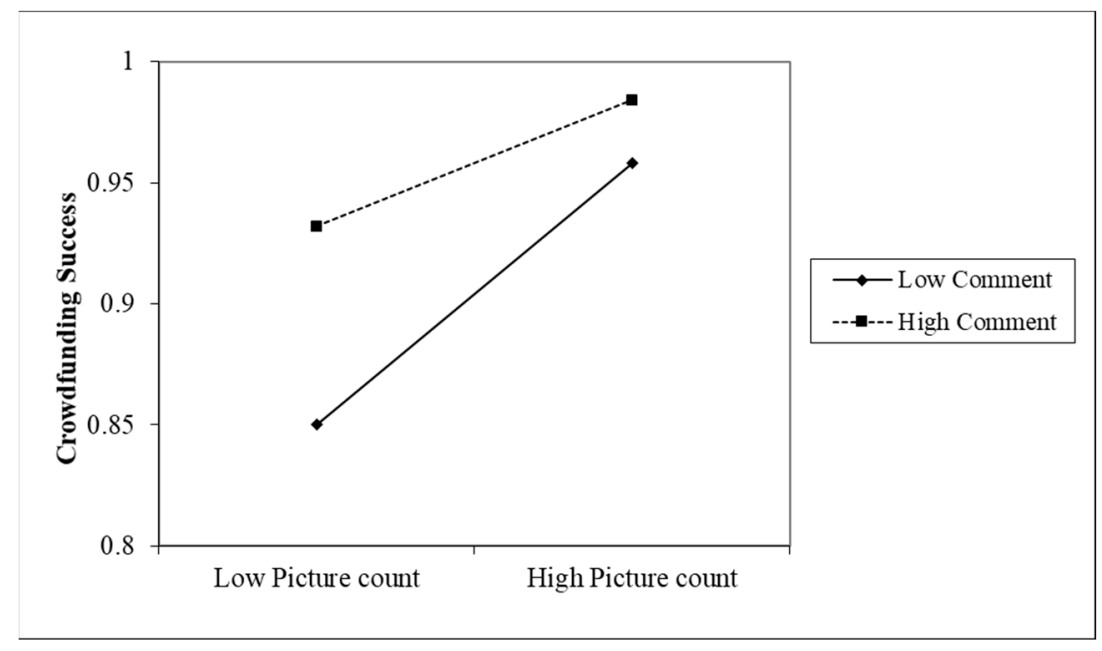

Figure 3. Moderating effect of comment on the relationship between picture count and crowdfunding success.

\section{Conclusions and Discussion}

To examine the impacts of information description on crowdfunding success, we consider three dimensions of information description including information quantity, information attitude, and information quality from the perspective of information communication. We measure information quantity as the word count, picture count and video count. We measure information quality as the readability and update. Information attitude is measured by comment. Using these variables, we are able to make hypotheses between information description and crowdfunding success, and we collect data $(N=7207)$ from the Kickstarter website to test the hypotheses.

Our results indicate that the number of words in project description is associated with crowdfunding success in an inverted-U shape. Most previous studies only explained the positive linear relationship between word count and crowdfunding performance $[21,29,30]$. This research gives evidence that the relationship is nonlinear. Too much information can increase the complexity of understanding crowdfunding projects, which cause aversion of backers and reduce the rate of crowdfunding success. As shown in Figure 2, if the word count of project description exceeds 2013, the effect of word count on crowdfunding success becomes negative.

Moreover, the number of pictures, videos, comments and updates are all positively associated with crowdfunding success. These are consistent with previous research findings $[1,23,29,40,52,61]$. Pictures and videos can help backers quickly understand the information of project. More pictures and videos in project description not only provide more detailed information but also increase persuasiveness. Maintaining continuous communication plays an important role in the process of crowdfunding success. Frequently updating project description is the best way to communicate with backers, which allows creators to show the new development of projects. This way can increase the trust of backers and provide opportunities to attract potential investors. Comments convey reviews, opinions or attitudes of backers, and more comments represent the popularity and good word-of-mouth of the project. What is more, backers usually choose to invest the projects with more comments. Therefore, more comments are beneficial to the success of crowdfunding.

However, the readability negatively affects crowdfunding success. This is confusing because we have expected a positive relation. Since if the information description of the project is more readable, it will be easier for backers to understand and can help reduce the information asymmetry. Being easy to understand means the information description of project mainly consists of informal or easy words with a low Fog Index. Using the formal words (with a high Fog Index) to write information description may represent the professionalism of creators [88]. Therefore, backers have positive perception for the project and it increases the possibility of crowdfunding success. 
What is more, this research also aimed to find out how comment influences the effects of information quantity on crowdfunding success. Few papers pointed out the moderating effects of comment on information quantity. The results show that comment negatively moderates the relationship between the picture count and crowdfunding success. When there are more comments, the impact of the number of pictures will be weakened. This further illustrates the importance of comments. But it doesn't moderate the relationship between the word count or the video count and crowdfunding success.

\subsection{Theoretical and Practical Implications}

The theoretical implications of this research are fourfold. First, this study systematically investigates the influence of information description on crowdfunding success from the information communication perspective. Most of the previous studies only tested the influence of one or two dimensions of the information description $[1,23,29,35,38,61,89]$. In this study, we have considered all the information quantity, information quality and information attitude as the antecedent factors. Although some studies already contain three dimensions, more comprehensive variables are not included. Generally, there are three modes of presenting in project description including word, picture, and video. However, most previous studies only included one or two of them $[12,17,30-32,34,40,90]$. This study has contained all variables of word, picture and video. Therefore, the conclusions in the study can help explain the effects of information description on the crowdfunding success more scientifically and comprehensively. Based on the results, we can clearly clarify how each component of information description affects crowdfunding success, helping to explore relatively important components of information description in improving the crowdfunding success. In conclusion, this study exerts contributions to form a clearer understanding of the improvement of crowdfunding success based on information description.

Secondly, we have proved the inverted-U relationship between word count and crowdfunding success. That is to say, within a certain range, word count affects crowdfunding success positively but at a diminishing rate; excessive words lead to understanding burden of backers and reduce the rate of crowdfunding success. The result is rarely found in existing researches which have considered all three dimensions of information description. Most prior researches only proved the linear relationship between word count and crowdfunding success $[12,15,23,29,32]$. They claimed that the number of words affects crowdfunding success positively. More words in description of projects lead to higher rate of success. But they did not consider the negative effects of excessive words on success. In addition, some researches only tested the curvilinear relationship without considering other dimensions of information description [30]. Thus, our study testes the inverted-U influence of word count in the context of taking other possible influencers into consideration and contributes to the existing knowledge by providing an alternative explanation to the impact of the number of words on crowdfunding success.

Finally, to the best of our knowledge, our study is one of the first to examine the moderating role of comment on the relationships between information quantity and crowdfunding success. Prior studies only explained the direct impact of comments on crowdfunding success [38-40,61]. It is well-known that word of mouth plays an important role in consumer decision-making process. Similarly, comment significantly affects backers' decision in crowdfunding. A higher number of comments signals high quality and popularity. The findings show that comment count can reduce the effects of picture count on crowdfunding success. In other words, when deciding whether to invest in this project, backers tend to consider the others' attitudes and the number of comments. This is very useful for fundraisers in preparing the display of projects. The result also enriches the research of word-of-mouth on crowdfunding.

Practical implications of this study are as follows. First, it is very important to reduce information asymmetry for creators and backers. And it is critical for creators to provide as much detailed information as possible. For example, creators should display the projects through words, pictures and videos, because pictures and videos can spread more details. Due to the inverted-U shape between 
word count and crowdfunding success, the moderate number of words represents the optimal level. When there are too few words, it is not beneficial for potential backers to provide funds, because too little information will expose them to greater risks and uncertainties. However, when there are too much words, it will increase the understanding burden of backers and cause them to give up reading information. Figure 2 shows the inverted-U relationships between word count and crowdfunding success. And the variable word count is standardized. The actual value of the original variable is 2013, which represents the optimal level of word count. Thus, another useful suggestion for creators stems from evidence that word count in project description should less than 2013.

Second, high level of update frequency can also signal the quality of projects and represent the positive attitudes of creators. Thus, creators should update the project description frequently in order to inform backers the new development of projects, make backers learn more details timely and reduce information asymmetry.

Third, creators need to take the readability of words into consideration. Informal words are not conductive to crowdfunding success. Thus, fundraisers should avoid using informal words in order to show their professionalism. In this way, it can increase the trust of backers and increase the rate of crowdfunding success.

Finally, word-of-mouth is a key factor affecting backers' decision, and higher number of comments represent the popularity of the project and can make backers believe that the project has a good word-of-mouth. Therefore, creators should also pay attention to the role of comments. Encouraging backers to leave comments is beneficial to crowdfunding success. What is more, it is a good idea to interact with backers or reply to their questions through comments.

\subsection{Limitations and Future Directions}

Nevertheless, our research has also some limitations and it can provide opportunities for future research. First, there are other types of crowdfunding, such as patronage-based, lending-based, or equity-based crowdfunding. This study only collected data from reward-based crowdfunding platform. Furthermore, our data were collected from only one crowdfunding platform (Kickstarter). But there are other crowdfunding platforms, such as GoFundMe and Indiegogo. This limits the universality of our research results. Therefore, to expand on the basis of the findings, future research can study other types of crowdfunding and compare the different factors of crowdfunding success among them.

Second, our study focuses on the information description of project before the project starts. However, in order to reduce information asymmetry and increase the trust of backers, many fundraisers often update the project information during crowdfunding. Thus, the information description during updating has also effects on crowdfunding success. This suggests that a possible extension of the study is to consider the updated content of information.

Third, we only used the picture count and video count in the project description. In a crowdfunding platform, backers can evaluate the projects through the content and styles of pictures and videos, such as color, video length, and background music. However, we do not have the information from the website due to the technical restrictions.

Finally, we cannot control the personal characteristics of backers, such as age, gender, education, income, crowdfunding experience, or category interest, which may also affect their decisions. In the future, the research can be extended from the above aspects.

Author Contributions: Conceptualization, X.L., X.H., and J.J.; methodology, X.L., X.H., and J.J.; software, X.H.; formal analysis, X.H. and J.J.; data curation, X.H.; writing-Original draft preparation, X.H.; writing-Review and editing, X.L. and J.J.; visualization, X.H. and J.J.; funding acquisition, X.L. All authors have read and agreed to the published version of the manuscript.

Funding: This research was funded by the Humanities and Social Science of Ministry of Education Planning Fund, grant number 17YJA630050.

Conflicts of Interest: The authors declare no conflict of interest. 


\section{Appendix A}

Table A1. Summary of existing literature about crowdfunding success.

\begin{tabular}{|c|c|c|c|c|c|c|}
\hline Author (Year) & DV & Antecedents & Controls & Key Findings & Data Source & DataSize \\
\hline $\begin{array}{c}\text { Mollick (2014) } \\
{[1]}\end{array}$ & $\begin{array}{l}\text { crowdfunding } \\
\text { success }(0,1)\end{array}$ & $\begin{array}{l}\text { (1) Creator's characteristics: } \\
\text { Facebook friends } \\
\text { (2) Information description quality: } \\
\text { updates, spelling errors }(0,1) \text {; } \\
\text { quantity: video }(0,1) \\
\text { (3) Project's characteristics: distance }\end{array}$ & $\begin{array}{l}\text { goal, duration, category, } \\
\text { featured projects }(0,1)\end{array}$ & $\begin{array}{l}\text { (1) Personal networks(Facebook } \\
\text { friends) and underlying project } \\
\text { quality(video, spelling errors, } \\
\text { updates,) are associated with the } \\
\text { success of crowdfunding efforts, and } \\
\text { that geography is related to both the } \\
\text { type of projects proposed and } \\
\text { successful fundraising. } \\
\text { (2) Goal and duration are negatively } \\
\text { associated with success. }\end{array}$ & Kickstarter & 48,500 \\
\hline $\begin{array}{l}\text { Frydrych et al. } \\
\text { (2014) [16] }\end{array}$ & $\begin{array}{l}\text { successful projects' } \\
\text { characteristics }\end{array}$ & $\begin{array}{l}\text { (1) Project's characteristics: goal, } \\
\text { duration, total amount of funds, } \\
\text { funding ratio, number of backers, } \\
\text { funding per backer, reward levels } \\
\text { (3) Information description } \\
\text { quantity: video }(0,1) \\
\text { (4) Creator's characteristics: } \\
\text { founding team composition }\end{array}$ & l & $\begin{array}{l}\text { (1) Lower funding goal and shorter } \\
\text { duration signal legitimacy by setting } \\
\text { modest, achievable expectations. } \\
\text { (2) Narrative legitimacy may derive } \\
\text { more from the online platform } \\
\text { community than the video. }\end{array}$ & Kickstarter & 421 \\
\hline $\begin{array}{l}\text { Hörisch (2015) } \\
\text { [9] }\end{array}$ & $\begin{array}{l}\text { crowdfunding } \\
\text { success }(0,1)\end{array}$ & $\begin{array}{l}\text { Project's characteristics: } \\
\text { environmental orientation }(0,1)\end{array}$ & $\begin{array}{l}\text { non-profit campaigns }(0,1) \text {, } \\
\text { goal, video }(0,1) \text {, duration, } \\
\text { rewards }(0,1) \text {, fixed target } \\
\text { amount }(0,1)\end{array}$ & $\begin{array}{l}\text { There is no positive connection } \\
\text { between environmental orientation } \\
\text { and crowdfunding success. }\end{array}$ & Indiegogo & 585 \\
\hline $\begin{array}{l}\text { Colombo et al. } \\
\text { (2015) [18] }\end{array}$ & $\begin{array}{l}\text { (1) success }(0,1) \\
\text { (2) number of backers } \\
\text { pledging at one sixth } \\
\text { of duration } \\
\text { (3) total pledges at } \\
\text { one sixth of campaign } \\
\text { divided by target } \\
\text { capital }\end{array}$ & $\begin{array}{l}\text { Creator's characteristics: internal } \\
\text { social capital (number of projects } \\
\text { backed), internal social capital } \\
\text { square }\end{array}$ & $\begin{array}{l}\text { number of LinkedIn } \\
\text { connections, gender, duration, } \\
\text { goal, reward }(0,1) \text {, number of } \\
\text { pictures and videos, number of } \\
\text { external links, location } \\
(\mathrm{US}=1) \text {, category }\end{array}$ & $\begin{array}{l}\text { The influence of internal social } \\
\text { capital on the success is fully } \\
\text { mediated by the capital and backers } \\
\text { collected in the campaign's } \\
\text { early days. }\end{array}$ & Kickstarter & 669 \\
\hline
\end{tabular}


Table A1. Cont.

\begin{tabular}{|c|c|c|c|c|c|c|}
\hline Author (Year) & DV & Antecedents & Controls & Key Findings & Data Source & DataSize \\
\hline $\begin{array}{c}\text { Liao et al. (2015) } \\
\text { [19] }\end{array}$ & $\begin{array}{l}\text { crowdfunding } \\
\text { performance (ratio of } \\
\text { pledge over goal) }\end{array}$ & $\begin{array}{l}\text { (1) Project's characteristics: likes, } \\
\text { investment, type }(0,1) \\
\text { (2) Creator's characteristics: } \\
\text { external social capital (sharing, fans) }\end{array}$ & goal, duration & $\begin{array}{l}\text { (1) External social capital have } \\
\text { significant effect on crowdfunding } \\
\text { performance. } \\
\text { (2) The effect of internal and external } \\
\text { social capital on the success of a } \\
\text { campaign is fully moderated by the } \\
\text { type of the project. }\end{array}$ & $\begin{array}{l}\text { Zhongchou } \\
\text { (China) }\end{array}$ & 862 \\
\hline $\begin{array}{l}\text { Allison et al. } \\
\text { (2015) [47] }\end{array}$ & time to funding & $\begin{array}{l}\text { Information description-language: } \\
\text { intrinsic language(human interest } \\
\text { language and diversity language, } \\
\text { overall intrinsic cues), extrinsic } \\
\text { language(profit language, risk taking } \\
\text { language, overall extrinsic cues) }\end{array}$ & $\begin{array}{l}\text { country }(0,1) \text {, industry }(0,1) \text {, } \\
\text { field partner risk rating, } \\
\text { foreign exchange risk coverage, } \\
\text { loan size, }\end{array}$ & $\begin{array}{l}\text { Narrative language highlighting the } \\
\text { intrinsic motivation to help others } \\
\text { have stronger positive effects on } \\
\text { lenders than narrative language } \\
\text { framed as a business opportunity. }\end{array}$ & Kiva (US) & 36,665 \\
\hline $\begin{array}{l}\text { Calic and } \\
\text { Mosakowski } \\
\text { (2016) [91] }\end{array}$ & $\begin{array}{l}\text { (1) success }(0,1) \\
\text { (2) pledge amount }\end{array}$ & $\begin{array}{l}\text { Project's characteristics: } \\
\text { sustainability orientation }(0,1), \\
\text { creativity, third party endorsements }\end{array}$ & $\begin{array}{l}\text { project complexity, team or } \\
\text { individual, number of projects } \\
\text { launched by the creator, } \\
\text { Facebook friends, age in days } \\
\text { of Kickstarter at project launch, } \\
\text { number of projects previously } \\
\text { backed, project quality, goal, } \\
\text { duration, number of reward } \\
\text { levels }\end{array}$ & $\begin{array}{l}\text { (1) Sustainability orientation } \\
\text { positively affects funding success. } \\
\text { (2) This relationship is partially } \\
\text { mediated by project creativity and } \\
\text { third party endorsements. }\end{array}$ & Kickstarter & 392 \\
\hline $\begin{array}{l}\text { Thies et al. } \\
\text { (2016) [39] }\end{array}$ & funding decision & $\begin{array}{l}\text { (1) Information description } \\
\text { attitude: number of comments } \\
\text { (2) Project's characteristics: } \\
\text { popularity information (past number } \\
\text { of backers), number of Facebook } \\
\text { shares }\end{array}$ & $\begin{array}{l}\text { campaign category, number of } \\
\text { campaigns in the respective } \\
\text { categories, number of } \\
\text { campaign updates, total } \\
\text { funding amount in US dollars, } \\
\text { campaign runtime in days, } \\
\text { video }(0,1)\end{array}$ & $\begin{array}{l}\text { (1) The eWOM has a significant yet } \\
\text { weaker predictive power than } \\
\text { popularity information. } \\
\text { (2) Popularity information has a } \\
\text { more immediate effect on consumers' } \\
\text { funding behavior, its effectiveness } \\
\text { decays rather quickly, while the } \\
\text { impact of eWOM recedes more } \\
\text { slowly. }\end{array}$ & Indiegogo & 23,300 \\
\hline $\begin{array}{c}\text { Kromidha and } \\
\text { Robson (2016) } \\
\text { [61] }\end{array}$ & $\begin{array}{l}\text { success } \\
\text { (pledge/backer } \\
\text { ratio=amount } \\
\text { pledged per backer) }\end{array}$ & $\begin{array}{l}\text { (1) Creator's characteristics: } \\
\text { Facebook friends } \\
\text { (2) Project's characteristics: } \\
\text { Facebook shares } \\
\text { (3) Information description } \\
\text { attitude: number of comments; } \\
\text { quality: number of updates }\end{array}$ & $\begin{array}{l}\text { duration, location, industry, } \\
\text { time }\end{array}$ & $\begin{array}{l}\text { (1) Facebook friends, Facebook } \\
\text { shares and number of comments are } \\
\text { also positively statistically related to } \\
\text { the amount pledged per backer. } \\
\text { (2) The number of updates appears } \\
\text { with a positively signed coefficient, } \\
\text { but this is not statistically significant. }\end{array}$ & Kickstarter & 5000 \\
\hline
\end{tabular}


Table A1. Cont.

\begin{tabular}{|c|c|c|c|c|c|c|}
\hline Author (Year) & DV & Antecedents & Controls & Key Findings & Data Source & DataSize \\
\hline $\begin{array}{l}\text { Chen et al. } \\
\text { (2016) [92] }\end{array}$ & Percent goal & $\begin{array}{l}\text { (1) Project's characteristics: product } \\
\text { type, reward tiers } \\
\text { (2) Information description } \\
\text { quantity: length of the video, length } \\
\text { of textual pitches; quality: } \\
\text { professionalism, image valence; } \\
\text { form: appeal modes, message } \\
\text { frames }\end{array}$ & duration, goal & $\begin{array}{l}\text { Guilt appeals, utilitarian product } \\
\text { types, an emotional message frame, } \\
\text { and reward tiers were significantly } \\
\text { and positively related to the } \\
\text { percentage of the funding goals. }\end{array}$ & Kickstarter & 200 \\
\hline $\begin{array}{c}\text { Hobbs (2016) } \\
{[35]}\end{array}$ & $\begin{array}{l}\text { crowdfunding } \\
\text { success }(0,1)\end{array}$ & $\begin{array}{l}\text { (1) Information description-quality: } \\
\text { number of updates, pitch quality } \\
\text { (2) Creator's characteristics: } \\
\text { Facebook friends } \\
\text { (3) Project's characteristics: goal, } \\
\text { duration, total raised, number of } \\
\text { backers, number of rewards, reward } \\
\text { quality, Facebook shares, direct } \\
\text { network size, search results } \\
\text { (4) Others: number of campaigners }\end{array}$ & & $\begin{array}{l}\text { (1) Pitch quality, total raised, shares, } \\
\text { updates, backers, reward quality are } \\
\text { strong predictors to successful or } \\
\text { failed campaigns. } \\
\text { (2) Search results, number of } \\
\text { rewards, Facebook friends, DNS, } \\
\text { goal and duration are poor } \\
\text { predictors. }\end{array}$ & Kickstarter & 100 \\
\hline $\begin{array}{l}\text { Kim et al. (2016) } \\
\text { [93] }\end{array}$ & $\begin{array}{l}\text { success: funding ratio, } \\
\text { goal was reached, } \\
\text { total amount raised, } \\
\text { speed, number of } \\
\text { funders }\end{array}$ & $\begin{array}{l}\text { Information description-language: } \\
\text { (1) quantifiers } \\
\text { (2) difference } \\
\text { (3) conjunctions } \\
\text { (4) insight }\end{array}$ & $\begin{array}{l}\text { total word count, pronouns, } \\
\text { positive emotion, negative } \\
\text { emotion, goal, duration, } \\
\text { campaign completed }(0,1) \text {, } \\
\text { number of creators, number of } \\
\text { campaigns, number of referrals, } \\
\text { number of funders, number of } \\
\text { updates, video }(0,1) \text {, number of } \\
\text { images, subtitle }(0,1) \text {, US }(0,1) \text {, } \\
\text { type }\end{array}$ & $\begin{array}{l}\text { (1) Words demonstrating precision } \\
\text { (quantifiers) and distinction } \\
\text { (differences) were both positively } \\
\text { associated with higher fundraising } \\
\text { achievements. } \\
\text { (2) Complexity (conjunctions) and } \\
\text { personal speculation (insight words) } \\
\text { were both negatively associated with } \\
\text { fundraising returns. }\end{array}$ & Indiegogo & 30,606 \\
\hline $\begin{array}{l}\text { Cumming et al. } \\
\text { (2016) [79] }\end{array}$ & $\begin{array}{l}\text { (1) success }(0,1) \\
\text { (2) pledged amount } \\
\text { (3) number of backers }\end{array}$ & $\begin{array}{l}\text { Project's characteristics: fraud } \\
\text { period }\end{array}$ & $\begin{array}{l}\text { goal, duration, featured }(0,1) \text {, } \\
\text { waiting time, category, year, } \\
\text { day of week, month of year, } \\
\text { day of month }\end{array}$ & $\begin{array}{l}\text { The occurrence of fraudulent } \\
\text { campaigns has negative effects on } \\
\text { future crowdfunding campaigns that } \\
\text { begin around suspension dates. }\end{array}$ & Kickstarter & 271,971 \\
\hline
\end{tabular}


Table A1. Cont.

\begin{tabular}{|c|c|c|c|c|c|c|}
\hline Author (Year) & DV & Antecedents & Controls & Key Findings & Data Source & DataSize \\
\hline $\begin{array}{l}\text { Kunz et al. } \\
\text { (2016) [23] }\end{array}$ & project success $(0,1)$ & $\begin{array}{l}\text { (1) Project's characteristics: duration, } \\
\text { rewards count, rewards limit }(0,1) \text {, } \\
\text { average delivery time, home page } \\
(0,1) \text {,preparation time, FAQ count, staff } \\
\text { pick }(0,1) \\
\text { (2) Creator's characteristics: Facebook } \\
\text { friends, number of project backings of } \\
\text { creator, } \\
\text { (3) Information description quantity: } \\
\text { number of words, number of images, } \\
\text { number of videos quality: update count } \\
\text { (4) Others: Facebook buzz }\end{array}$ & goal & $\begin{array}{l}\text { (1) Social ties, investment preparation } \\
\text { and presentation, multiple rewards as } \\
\text { well as communication and interaction } \\
\text { with the backers positively influence } \\
\text { the probability of success. } \\
\text { (2) The goal, duration and the } \\
\text { estimated time of delivery for the } \\
\text { rewards have a negative impact } \\
\text { on success. }\end{array}$ & Kickstarter & 136,886 \\
\hline $\begin{array}{l}\text { Parhankangas } \\
\text { and Renko } \\
\text { (2017) [24] }\end{array}$ & $\begin{array}{l}\text { crowdfunding } \\
\text { success }(0,1)\end{array}$ & $\begin{array}{l}\text { (1) Information description form: } \\
\text { Linguistic style } \\
\text { (2) Project's characteristics: category } \\
\text { (social, commercial) }\end{array}$ & $\begin{array}{l}\text { campaign country (US = 1), } \\
\text { funding goal, Facebook friends, } \\
\text { entrepreneurs' previous } \\
\text { successful crowdfunding } \\
\text { campaigns, the number of } \\
\text { words, the use of numerical } \\
\text { terms, gender, ethnicity, } \\
\text { collective language, Flesch } \\
\text { Reading Ease, positive emotion } \\
\text { words, motion words, } \\
\text { exclusion words, language } \\
\text { describing social problems, } \\
\text { language describing } \\
\text { innovativeness, language } \\
\text { describing market orientation }\end{array}$ & $\begin{array}{l}\text { Linguistic styles boost the success of } \\
\text { social campaigns, but hardly matter } \\
\text { for commercial campaigns. }\end{array}$ & Kickstarter & 656 \\
\hline $\begin{array}{c}\text { Courtney et al. } \\
\text { (2017) [33] }\end{array}$ & $\begin{array}{l}\text { crowdfunding } \\
\text { success }(0,1)\end{array}$ & $\begin{array}{l}\text { (1) Information description quantity: } \\
\text { media (images or videos;0,1); attitude: } \\
\text { backer sentiment (reflected in comments) } \\
\text { (2) Creator's characteristics: past } \\
\text { success (past success: number of projects } \\
\text { that creators successfully crowdfunded). }\end{array}$ & $\begin{array}{l}\text { goal, duration, spelling error, } \\
\text { number of words, quick } \\
\text { updates, number of rewards, } \\
\text { Facebook shares, number of } \\
\text { comments, Facebook friends, } \\
\text { external web links, category, } \\
\text { year }\end{array}$ & $\begin{array}{l}\text { (1) Use of media and founders' prior } \\
\text { crowdfunding success and positive } \\
\text { backer sentiments all have positive } \\
\text { effects on crowdfunding success. } \\
\text { (2) The positive effect of use of media } \\
\text { on crowdfunding success decreases } \\
\text { with the founder's past success. } \\
\text { (3) The positive effects of media usage } \\
\text { and past success on crowdfunding } \\
\text { success increase with the intensity of } \\
\text { positive backer sentiment. }\end{array}$ & Kickstarter & 267,295 \\
\hline
\end{tabular}


Table A1. Cont.

\begin{tabular}{|c|c|c|c|c|c|c|}
\hline Author (Year) & DV & Antecedents & Controls & Key Findings & Data Source & DataSize \\
\hline $\begin{array}{l}\text { Buttice et al. } \\
\text { (2017) [80] }\end{array}$ & Success $(0,1)$ & $\begin{array}{l}\text { Creator's characteristics: } \\
\text { (1) Number of previous successful } \\
\text { campaigns } \\
\text { (2) Number of previous unsuccessful } \\
\text { campaigns } \\
\text { (3) Social capital from successful } \\
\text { campaigns: cumulative number of } \\
\text { comments in previous successful } \\
\text { campaigns } \\
\text { (4) Social capital from backing activity: the } \\
\text { number of comments that creators had } \\
\text { posted on backed projects } \\
\text { (5) External social capital: Facebook friend } \\
\text { (6) Others: time }\end{array}$ & $\begin{array}{l}\text { number of visuals (videos plus } \\
\text { images), number of links to } \\
\text { external websites, goal, } \\
\text { duration, country (US }=1 \text { ) staff } \\
\text { picks }(0,1) \text {, rewards }\end{array}$ & $\begin{array}{l}\text { (1) Serial crowdfunders' success is } \\
\text { mainly related to the internal social } \\
\text { capital consisting of the links with } \\
\text { backers of previous successful } \\
\text { campaigns. } \\
\text { (2) Social capital from previously } \\
\text { successful campaigns has decreasing } \\
\text { effect on success likelihood of } \\
\text { subsequent crowdfunding } \\
\text { campaigns over time. }\end{array}$ & Kickstarter & 31,389 \\
\hline $\begin{array}{l}\text { Bi et al. (2017) } \\
\text { [29] }\end{array}$ & $\begin{array}{l}\text { number of invested } \\
\text { funders }\end{array}$ & $\begin{array}{l}\text { (1) Information description quantity: } \\
\text { word count, video count; attitude: } \\
\text { number of reviews } \\
\text { (2) Project's characteristics: "Like" count }\end{array}$ & goal, duration & $\begin{array}{l}\text { (1) Signals of quality (word count } \\
\text { and video count) and electronic } \\
\text { word of mouth ("Like" count and } \\
\text { number of reviews) have significant } \\
\text { positive effects on funder investment. } \\
\text { (2) The central route information } \\
\text { (signals of project quality) and the } \\
\text { peripheral route information (e-word } \\
\text { of mouth) have similar effects on } \\
\text { funder investment decisions in the } \\
\text { Chinese crowdfunding context. }\end{array}$ & $\begin{array}{l}\text { Zhongchou } \\
\text { (China) }\end{array}$ & 1407 \\
\hline $\begin{array}{l}\text { Allison et al. } \\
\text { (2017) [2] }\end{array}$ & $\begin{array}{l}\text { crowdfunding } \\
\text { success }(0,1)\end{array}$ & $\begin{array}{l}\text { (1) Creator's characteristics: entrepreneur } \\
\text { education }(0,1) \text {, entrepreneur experience } \\
(0,1) \text {, entrepreneur's dream }(0,1) \text {, group } \\
\text { identity }(0,1) \text {, moderator: funder } \\
\text { experience } \\
\text { (2) Information description-form: } \\
\text { positive narrative tone } \\
\text { (3) Project's characteristics: ingredient } \\
\text { branding }(0,1) \text {, product interconnections } \\
(0,1) \text {, moderator: funding commitments }\end{array}$ & $\begin{array}{l}\text { location, industry, lead } \\
\text { entrepreneur race, lead } \\
\text { entrepreneur gender, TMT size, } \\
\text { social network shares, the } \\
\text { presence of extrinsic rewards, } \\
\text { venture development stage, } \\
\text { and funding goal. }\end{array}$ & $\begin{array}{l}\text { (1) Entrepreneur education is } \\
\text { negatively correlated to } \\
\text { crowdfunding success. } \\
\text { (2) Entrepreneur experience, } \\
\text { ingredient branding, product } \\
\text { interconnections, entrepreneur's } \\
\text { dream and group identity are all } \\
\text { significant and positive effects. } \\
\text { (3) Positive tone has positive } \\
\text { influence but it does not reach } \\
\text { significance. } \\
\text { (4) Funding commitments and } \\
\text { funder experience are positive and } \\
\text { significant moderators. }\end{array}$ & Kickstarter & 383 \\
\hline
\end{tabular}


Table A1. Cont.

\begin{tabular}{|c|c|c|c|c|c|c|}
\hline Author (Year) & DV & Antecedents & Controls & Key Findings & Data Source & DataSize \\
\hline $\begin{array}{l}\text { Barbi and Bigelli } \\
\text { (2017) [22] }\end{array}$ & $\begin{array}{l}\text { crowdfunding } \\
\text { success }(0,1)\end{array}$ & $\begin{array}{l}\text { (1) Project's characteristics: goal, } \\
\text { duration, reward levels } \\
\text { (2) Information description } \\
\text { quantity: video }(0,1) \text {, description } \\
\text { length, squared description length }\end{array}$ & $\begin{array}{l}\text { fixed effects: category, country, } \\
\text { year }\end{array}$ & $\begin{array}{l}\text { The crowdfunding success is driven } \\
\text { by the presence of a video, a higher } \\
\text { number of rewards, a shorter } \\
\text { campaign, and a lower goal. A more } \\
\text { extensive description signals higher } \\
\text { quality and helps the funding, unless } \\
\text { it becomes too prolix. Thus, the } \\
\text { relationship between description } \\
\text { length and success is inverted-U. }\end{array}$ & Kickstarter & 105,997 \\
\hline $\begin{array}{l}\text { Block et al. } \\
\text { (2017) [36] }\end{array}$ & $\begin{array}{l}\text { (1) number of } \\
\text { investments } \\
\text { (2) amount of capital } \\
\text { pledged }\end{array}$ & $\begin{array}{l}\text { Information description quality: } \\
\text { (1) number of updates } \\
\text { (2) Flesch Index (language } \\
\text { complexity) } \\
\text { (3) text length of an update } \\
\text { (4) update categories }\end{array}$ & $\begin{array}{l}\text { amount (until } \mathrm{t}-1 \text { ), investors } \\
\text { (until } \mathrm{t}-1 \text { ), number of active } \\
\text { campaigns, number of } \\
\text { competing investments, post } \\
\text { funded, equity share, } \\
\text { Seedmatch }\end{array}$ & $\begin{array}{l}\text { (1) Posting an update has a } \\
\text { significant positive effect on the } \\
\text { number of investments and the } \\
\text { amount of capital pledged. But the } \\
\text { effect loses statistical significance } \\
\text { with the number of updates posted } \\
\text { during a campaign. } \\
\text { (2) Easier language used in updates } \\
\text { has positive effects, whereas the } \\
\text { length of updates has no effects. } \\
\text { (3) Update's content about new } \\
\text { developments of the start-up such as } \\
\text { campaign developments, new } \\
\text { funding business developments, and } \\
\text { cooperation projects has positive } \\
\text { effects. }\end{array}$ & $\begin{array}{l}\text { Companisto } \\
\text { (Germany), } \\
\text { Seedmatch } \\
\text { (Germany) }\end{array}$ & $\begin{array}{l}\text { equity } \\
\text { projects }\end{array}$ \\
\hline $\begin{array}{l}\text { Pietraszkiewicz } \\
\text { et al. (2017) [84] }\end{array}$ & $\begin{array}{l}\text { (1) success }(0,1) \\
\text { (2) number of backers } \\
\text { (3) Facebook shares }\end{array}$ & $\begin{array}{l}\text { Information description quantity: } \\
\text { the percentage of prosocial words }\end{array}$ & $\begin{array}{l}\text { number of rewards, video }(0,1) \text {, } \\
\text { number of images, number of } \\
\text { updates, goal, duration, } \\
\text { category }\end{array}$ & $\begin{array}{l}\text { The higher the percentage of } \\
\text { prosocial words in a project's } \\
\text { description, the larger the number of } \\
\text { investors and the greater the chances } \\
\text { of reaching a funding goal. }\end{array}$ & Kickstarter & 164,056 \\
\hline $\begin{array}{l}\text { Kang et al. } \\
\text { (2017) [20] }\end{array}$ & funding amount & $\begin{array}{l}\text { (1) Project's characteristics: } \\
\text { geographical distance } \\
\text { (2) Creator's characteristics: social } \\
\text { capital }\end{array}$ & $\begin{array}{l}\text { goal, word count, image count, } \\
\text { video count, category, time } \\
\text { trend, accumulative fund } \\
\text { amount, fund amount from } \\
\text { non-Weibo funders, gender, } \\
\text { platform follower number, } \\
\text { Weibo follower number, } \\
\text { valuable follower number }\end{array}$ & $\begin{array}{l}\text { Higher funding can be secured with } \\
\text { backers who are (1) of further } \\
\text { geographical distance and } \\
\text { (2) of higher social capital. }\end{array}$ & $\begin{array}{l}\text { Demohour } \\
\text { (China) }\end{array}$ & 442 \\
\hline
\end{tabular}


Table A1. Cont.

\begin{tabular}{|c|c|c|c|c|c|c|}
\hline Author (Year) & DV & Antecedents & Controls & Key Findings & Data Source & DataSize \\
\hline $\begin{array}{c}\text { Lagazio and } \\
\text { Querci (2018) } \\
{[15]}\end{array}$ & $\begin{array}{l}\text { (1) crowdfunding } \\
\text { success }(0.1) \\
\text { (2) amount received } \\
\text { (3) backers } \\
\text { (4) average funds }\end{array}$ & $\begin{array}{l}\text { (1)Project's characteristics: sector } \\
\text { (social or non-social), type of } \\
\text { funding(“all or nothing" or "take it } \\
\text { all"), goal, duration, external } \\
\text { websites(0,1) } \\
\text { (2) Creator's characteristics: team } \\
\text { members } \\
\text { (3) Information description } \\
\text { quantity: video(0,1), length(number } \\
\text { of words); quality: updates( }(0,1) \text {; } \\
\text {-attitude: comments( }(0,1) \text {; form: } \\
\text { language(English, Italian) }\end{array}$ & & $\begin{array}{l}\text { (1) Fixed campaigns, projects } \\
\text { supported by teams including at } \\
\text { least five members and last over } 30 \\
\text { days are more likely to achieve their } \\
\text { goals. } \\
\text { (2) Goal, using a video to introduce } \\
\text { projects and presenting projects in } \\
\text { Italian, social impact initiatives all } \\
\text { decrease funding success. } \\
\text { (3) Longer descriptions, updates, } \\
\text { comments, links to external website } \\
\text { are all positively related to success. }\end{array}$ & Indiegogo & 1507 \\
\hline $\begin{array}{l}\text { Zhou et al. } \\
\text { (2018) [12] }\end{array}$ & $\begin{array}{l}\text { crowdfunding } \\
\text { success }(0,1)\end{array}$ & $\begin{array}{l}\text { (1) Information description } \\
\text { quantity: length (number of words); } \\
\text { quality: readability; tone, tone } \\
\text { square } \\
\text { (2) Creator's characteristics: past } \\
\text { experience; past expertise }\end{array}$ & $\begin{array}{l}\text { duration, goal, Facebook }(0,1), \\
\text { Facebook friends, number of } \\
\text { image, number of videos, } \\
\text { rewards (number of levels), } \\
\text { year, category }\end{array}$ & $\begin{array}{l}\text { (1) Length positively affects } \\
\text { crowdfunding success. } \\
\text { (2) Readability is negatively affects } \\
\text { crowdfunding success. } \\
\text { (3) The relationship between tone } \\
\text { and crowdfunding success is } \\
\text { invert-U shape. } \\
\text { (4) Past Experience and past } \\
\text { Expertise positively affect success. }\end{array}$ & Kickstarter & 151,752 \\
\hline $\begin{array}{l}\text { Chan et al. } \\
\text { (2018) [94] }\end{array}$ & $\begin{array}{l}\text { (1) crowdfunding } \\
\text { success }(0,1) \\
\text { (2) number of backers } \\
\text { (3) pledge amount }\end{array}$ & $\begin{array}{l}\text { (1) project characteristics } \\
\text { (2) entrepreneur characteristics } \\
\text { (3) product category } \\
\text { (4) location }\end{array}$ & & $\begin{array}{l}\text { (1) Project characteristics and } \\
\text { entrepreneur characteristics have the } \\
\text { highest effects on crowdfunding } \\
\text { outcomes (over } 80 \% \text { of total } \\
\text { variance). } \\
\text { (2) Product category and location } \\
\text { have lower effects on crowdfunding } \\
\text { outcomes. }\end{array}$ & Kickstarter & 98,336 \\
\hline $\begin{array}{c}\text { Davies and } \\
\text { Giovannetti } \\
(2018)[13]\end{array}$ & $\begin{array}{l}\text { crowdfunding } \\
\text { success }(0,1)\end{array}$ & $\begin{array}{l}\text { (1) Creator's characteristics: } \\
\text { previously created campaigns, } \\
\text { previously backed campaigns, } \\
\text { Facebook friends } \\
\text { (2) Project's characteristics: goal, } \\
\text { duration, early funds, early backers }\end{array}$ & $\begin{array}{l}\text { category, location (USA, } \\
\text { Europe, Asia, Africa) }\end{array}$ & $\begin{array}{l}\text { (1) Signaling about a project's creator } \\
\text { experience (previously created } \\
\text { campaigns), previously backed } \\
\text { campaigns, early funding, early } \\
\text { backing and external social capital } \\
\text { have positive effects on success. } \\
\text { (2) Goal and duration all have } \\
\text { negative effects on success. }\end{array}$ & Kickstarter & 10,000 \\
\hline
\end{tabular}


Table A1. Cont.

\begin{tabular}{|c|c|c|c|c|c|c|}
\hline Author (Year) & DV & Antecedents & Controls & Key Findings & Data Source & DataSize \\
\hline $\begin{array}{l}\text { Anglin et al. } \\
\text { (2018) [5] }\end{array}$ & $\begin{array}{l}\text { crowdfunding } \\
\text { success }(0,1)\end{array}$ & $\begin{array}{l}\text { (1) Information description-form: } \\
\text { positive psychological capital } \\
\text { (language) } \\
\text { (2) Creator's characteristics: social } \\
\text { capital (number of projects backed, } \\
\text { endorsements), human capital } \\
\text { (entrepreneurial experience) }\end{array}$ & $\begin{array}{l}\text { category, goal, duration, year } \\
(0,1) \text { video }(0,1) \text {, Facebook } \\
\text { friends, word length, education } \\
(0,1) \text {, staff pick }(0,1) \text {, outside } \\
\text { web }(0,1) \text {, sex, ethnicity }\end{array}$ & $\begin{array}{l}\text { Positive psychological capital experience } \\
\text { superior fundraising performance. } \\
\text { Human capital moderates this } \\
\text { relationship while social capital } \\
\text { does not. }\end{array}$ & Kickstarter & 1726 \\
\hline $\begin{array}{l}\text { Wang et al. } \\
\text { (2018) [38] }\end{array}$ & $\begin{array}{l}\text { crowdfunding } \\
\text { success }(0,1)\end{array}$ & $\begin{array}{l}\text { Information description attitude: } \\
\text { (1) comment quantity } \\
\text { (2) comment sentiment } \\
\text { (3) comment length } \\
\text { (4) reply ratio } \\
\text { (5) reply length } \\
\text { (6) reply speed }\end{array}$ & $\begin{array}{l}\text { goal, duration, video }(0,1), \\
\text { picture (number), update, } \\
\text { experience as backers, } \\
\text { experience as creators }\end{array}$ & $\begin{array}{l}\text { (1) Comment quantity, comment score, } \\
\text { reply length, and reply speed are } \\
\text { positively associated with the } \\
\text { fundraising success. } \\
\text { (2) Comment sentiment positively } \\
\text { moderates the effect of comment } \\
\text { quantity on crowdfunding success. }\end{array}$ & $\begin{array}{l}\text { Dreamore } \\
\text { (China) }\end{array}$ & 959 \\
\hline $\begin{array}{c}\text { Petitjean (2018) } \\
\text { [40] }\end{array}$ & $\begin{array}{l}\text { crowdfunding } \\
\text { success }(0,1)\end{array}$ & $\begin{array}{l}\text { (1) Project's characteristics: goal, } \\
\text { past success by category,1st week } \\
\text { backers,1st week total pledge,1st } \\
\text { week funded, geography, websites } \\
\text { (0,1), shares } \\
\text { (2) Creator's characteristics: } \\
\text { Facebook friends } \\
\text { (3) Information description } \\
\text { quantity: photos }(0,1) \text {, videos }(0,1) \text {; } \\
\text {-quality: updates(number); attitude: } \\
\text { comments(number) }\end{array}$ & / & $\begin{array}{l}\text { (1) Goal has a negative effect on success. } \\
\text { (2) The past success rate observed by } \\
\text { project category before the launch of the } \\
\text { project have positive effects. } \\
\text { (3) The first week of the campaign is } \\
\text { very informative when it comes to } \\
\text { determining its ultimate success. } \\
\text { (4) Comments affects positively success. } \\
\text { (5) This study did not find evidence that } \\
\text { geographical factors, Facebook friends, } \\
\text { update, shares, pictures and website are } \\
\text { associated with success. It only finds } \\
\text { that video has positive and significant } \\
\text { effect under specific conditions. }\end{array}$ & $\begin{array}{l}\text { KissKissBankBank } \\
\quad \text { (France) }\end{array}$ & 160 \\
\hline Xu (2018) [27] & $\begin{array}{l}\text { (1) total donation } \\
\text { (2) average donation } \\
\text { per donor }\end{array}$ & $\begin{array}{l}\text { (1) Information description } \\
\text { quantity: number of videos, number } \\
\text { of pictures, number of text (different } \\
\text { topic words) } \\
\text { (2) Project's characteristics: } \\
\text { category }\end{array}$ & $\begin{array}{l}\text { time, goal, number of } \\
\text { "Favorites," number of updates, } \\
\text { Facebook friends, number of } \\
\text { shares (Facebook and Twitter). }\end{array}$ & $\begin{array}{l}\text { (1) Having more videos and pictures } \\
\text { predicted increase in donation, the } \\
\text { increase was unevenly distributed } \\
\text { across different categories of projects. } \\
\text { (2) Topic words relating to factual details } \\
\text { positively predicted the fundraising } \\
\text { outcomes, but overusing words such as } \\
\text { "help," "money," and "thank" seemed } \\
\text { to backfire. }\end{array}$ & $\begin{array}{l}\text { donation-based } \\
\text { crowdfunding } \\
\text { platform }\end{array}$ & 4123 \\
\hline
\end{tabular}


Table A1. Cont.

\begin{tabular}{|c|c|c|c|c|c|c|}
\hline Author (Year) & DV & Antecedents & Controls & Key Findings & Data Source & DataSize \\
\hline $\begin{array}{l}\text { Gafni et al. } \\
\text { (2018) [95] }\end{array}$ & $\begin{array}{l}\text { (1) crowdfunding } \\
\text { success }(0,1) \\
\text { (2) pledge ratio } \\
\text { (3) number of backers }\end{array}$ & Project's characteristics: mentions & $\begin{array}{l}\text { category, goal, previous } \\
\text { success, video, total words, } \\
\text { website, location }\end{array}$ & $\begin{array}{l}\text { Entrepreneurs' descriptions } \\
\text { matter-projects (especially art } \\
\text { related) that frequently mentioned } \\
\text { entrepreneurs' names experienced } \\
\text { higher rates of success. }\end{array}$ & Kickstarter & 20,224 \\
\hline $\begin{array}{l}\text { Moy et al. (2018) } \\
\text { [30] }\end{array}$ & $\begin{array}{l}\text { crowdfunding success } \\
\text { (amount raised, } \\
\text { number of backers) }\end{array}$ & $\begin{array}{l}\text { Information description quantity: } \\
\text { information quantity (word count) }\end{array}$ & $\begin{array}{l}\text { goal, category, duration, } \\
\text { duration square, geographic } \\
\text { location, creator experience, } \\
\text { competition, edits }\end{array}$ & $\begin{array}{l}\text { The study demonstrates a clear } \\
\text { inverted-U relation between the } \\
\text { amount of descriptive text and } \\
\text { crowdfunding success. Excess } \\
\text { information will negatively affect } \\
\text { funds raised and number of backers. }\end{array}$ & Kickstarter & 81,892 \\
\hline $\begin{array}{l}\text { Guo et al. (2018) } \\
\text { [96] }\end{array}$ & $\begin{array}{l}\text { crowdfunding } \\
\text { success }(0,1)\end{array}$ & $\begin{array}{l}\text { Project's characteristics: distance } \\
\text { diffusion of home bias }\end{array}$ & $\begin{array}{l}\text { updates, comments, goal, } \\
\text { duration, pledge level, video, } \\
\text { number of preceding, number } \\
\text { of followers, max pledge, min } \\
\text { pledge, average pledge, } \\
\text { population density }\end{array}$ & $\begin{array}{l}\text { For most of the campaigns, the } \\
\text { distance between backers and } \\
\text { founders of the successful campaigns } \\
\text { is always greater than that of the } \\
\text { failed ones; thus, the distance } \\
\text { diffusion impacts the pledge results. }\end{array}$ & Kickstarter & 136,234 \\
\hline $\begin{array}{l}\text { Schäfer et al. } \\
\text { (2018) [97] }\end{array}$ & $\begin{array}{l}\text { crowdfunding success } \\
\text { (funding level) }\end{array}$ & $\begin{array}{l}\text { (1) Project's characteristics: targeted } \\
\text { amount, perks, personalization, } \\
\text { scientific scope, humor } \\
\text { (2) Creator's characteristics: } \\
\text { academic title of applicant, prices } \\
\text { and honors of applicant } \\
\text { (3) Information description } \\
\text { quantity: project description length } \\
\text { (number of words), visualization } \\
\text { (number of images and videos); } \\
\text { quality: project description } \\
\text { complexity, reference to elite persons } \\
\text { (4) Others: security of payment, } \\
\text { convenience of payment, number of } \\
\text { monthly users, platform focus, } \\
\text { interactivity, media features or } \\
\text { testimonials of project or platform, } \\
\text { scientific platform sponsor, } \\
\text { astonishment }\end{array}$ & discipline $(0,1)$ & $\begin{array}{l}\text { (1) Projects presented on } \\
\text { science-only crowdfunding } \\
\text { platforms have a higher success rate. } \\
\text { (2) Projects are more likely to be } \\
\text { successful if their presentation } \\
\text { includes visualizations and humor, } \\
\text { the lower their targeted funding is, } \\
\text { the less personal data potential } \\
\text { donors have to relinquish and the } \\
\text { more interaction between } \\
\text { researchers and donors is possible. }\end{array}$ & $\begin{array}{l}11 \\
\text { crowdfunding } \\
\text { platforms }\end{array}$ & 371 \\
\hline
\end{tabular}


Table A1. Cont.

\begin{tabular}{|c|c|c|c|c|c|c|}
\hline Author (Year) & DV & Antecedents & Controls & Key Findings & Data Source & DataSize \\
\hline $\begin{array}{l}\text { Clauss et al. } \\
\text { (2018) [89] }\end{array}$ & $\begin{array}{l}\text { crowdfunding } \\
\text { success }(0,1)\end{array}$ & $\begin{array}{l}\text { Information description attitude: } \\
\text { number of comments from the } \\
\text { crowd, project owner comments, last } \\
\text { comment positive; quality: updates }\end{array}$ & $\begin{array}{l}\text { number of other projects, } \\
\text { number projects supported, } \\
\text { individual person }(0,1) \text {, goal, } \\
\text { pictures }(0,1) \text {, picture of the } \\
\text { project owner, video }(0,1), \\
\text { Facebook }(0,1) \text {, additional } \\
\text { homepage }(0,1) \text {, duration, } \\
\text { rewards, industry }\end{array}$ & $\begin{array}{l}\text { Social interaction during a } \\
\text { crowdfunding campaign increases } \\
\text { the likelihood of its success. }\end{array}$ & $\begin{array}{l}\text { Visionbakey } \\
\text { (Germany) }\end{array}$ & 430 \\
\hline Shi (2018) [28] & $\begin{array}{l}\text { number of backers, } \\
\text { revenue }\end{array}$ & $\begin{array}{l}\text { Project's characteristics: } \\
\text { (1) reward limit } \\
\text { (2) reward tier } \\
\text { (3) price }\end{array}$ & $\begin{array}{l}\text { reward growth rate, different } \\
\text { delivery time, product, } \\
\text { accessories, Thank You, } \\
\text { creative mementos, creative } \\
\text { experiences, creative } \\
\text { collaborations, friends, } \\
\text { exclusive edition, early access }\end{array}$ & $\begin{array}{l}\text { (1) The effect of reward limit setting } \\
\text { on funding outcomes varies by } \\
\text { reward tiers. } \\
\text { (2) Higher tiers reduce price } \\
\text { sensitivity. } \\
\text { (3) For reward type, in lower reward } \\
\text { tiers, material rewards are better } \\
\text { received than symbolic ones. }\end{array}$ & $\begin{array}{l}\text { US } \\
\text { crowdfunding } \\
\text { platform }\end{array}$ & 219 \\
\hline $\begin{array}{l}\text { Borst et al. } \\
\text { (2018) [52] }\end{array}$ & $\begin{array}{l}\text { project performance } \\
\text { (daily amount } \\
\text { donated per project) }\end{array}$ & $\begin{array}{l}\text { (1) Information description quality: } \\
\text { lagged number of updates } \\
\text { (2) Creator's characteristics: lagged } \\
\text { number of Facebook messages, } \\
\text { lagged number of messages on } \\
\text { Twitter, tie strength (strong ties, } \\
\text { weak ties, latent ties) }\end{array}$ & lagged project performance & $\begin{array}{l}\text { (1) Prior project performance } \\
\text { positively affects current-day project } \\
\text { performance. } \\
\text { (2) Project updates and tweets have } \\
\text { positive effects on donation amounts } \\
\text { on the subsequent day. However, } \\
\text { Facebook messages do not show a } \\
\text { significant effect on project } \\
\text { performance. } \\
\text { (3) Strong ties, weak ties and latent } \\
\text { ties have significant and positive } \\
\text { effects. } \\
\text { (4) Sending more tweets negatively } \\
\text { interacted with weak and latent ties. }\end{array}$ & $\begin{array}{l}\text { Voordekunst } \\
\text { (Netherlands) } \\
\text { + interview }\end{array}$ & 271 \\
\hline $\begin{array}{c}\text { Vismara (2019) } \\
{[98]}\end{array}$ & $\begin{array}{l}\text { (1) success }(0,1) \\
\text { (2) number of } \\
\text { investors } \\
\text { (3) professional } \\
\text { investors }(0,1)\end{array}$ & $\begin{array}{l}\text { Project's characteristics: } \\
\text { sustainability orientation }(0,1)\end{array}$ & $\begin{array}{l}\text { Seedrs }(0,1) \text {, TMT size, founder } \\
\text { experience, goal, equity offered, } \\
\text { serial, tax incentives }\end{array}$ & $\begin{array}{l}\text { Sustainability orientation does not } \\
\text { increase the chances of success or of } \\
\text { engaging professional investors, it } \\
\text { attracts a higher number of restricted } \\
\text { investors. }\end{array}$ & $\begin{array}{l}\text { Crowdcube } \\
\text { and Seedrs }\end{array}$ & $\begin{array}{c}345 \text { equity } \\
\text { projects }\end{array}$ \\
\hline
\end{tabular}


Table A1. Cont.

\begin{tabular}{|c|c|c|c|c|c|c|}
\hline Author (Year) & DV & Antecedents & Controls & Key Findings & Data Source & DataSize \\
\hline $\begin{array}{l}\text { Chan et al. } \\
\text { (2019) [99] }\end{array}$ & $\begin{array}{l}\text { success: total amount } \\
\text { raised, number of } \\
\text { backers }\end{array}$ & $\begin{array}{l}\text { (1) Project's characteristics: } \\
\text { sustainability intention } \\
\text { (2) Information description } \\
\text { quantity: number of money saliency } \\
\text { words }\end{array}$ & $\begin{array}{l}\text { goal, duration, category, } \\
\text { geographic location, reward } \\
\text { tier, serial creator, team, share } \\
\text { of limited reward, reward } \\
\text { types, competition, spelling } \\
\text { errors, projects backed, social } \\
\text { media network, launch } \\
\text { day-of-week, end day-of-week. }\end{array}$ & $\begin{array}{l}\text { Using money saliency in text reduces its } \\
\text { funding success as measured by both } \\
\text { amount of funds raised and number of } \\
\text { backers. The effects of the saliency of } \\
\text { money is mitigated when the project is } \\
\text { prosocial. }\end{array}$ & Kickstarter & 80,000 \\
\hline $\begin{array}{l}\text { Zhang and } \\
\text { Chen (2019) [26] }\end{array}$ & $\begin{array}{l}\text { (1) number of backers } \\
\text { (2) crowdfunding } \\
\text { success }(0,1)\end{array}$ & $\begin{array}{l}\text { Project's characteristics: consumer } \\
\text { benefits(code), number of rewards }\end{array}$ & $\begin{array}{l}\text { days to go, funding period, } \\
\text { goal, location, currency }(0,1) \text {, } \\
\text { project history, technical } \\
\text { language }\end{array}$ & $\begin{array}{l}\text { (1) The number of backers increases the } \\
\text { likelihood of funding success. } \\
\text { (2) Consumer benefits have positive effects } \\
\text { on the number of backers. } \\
\text { (3) The average number of rewards affects } \\
\text { the number of backers in an inverted-U } \\
\text { shape, and it also moderates the } \\
\text { relationship between consumer benefits } \\
\text { and the number of backers in an } \\
\text { inverted-U shape. }\end{array}$ & $\begin{array}{l}\text { Kickstarter } \\
\text { (data + code) }\end{array}$ & $\begin{array}{l}674 \\
\text { technological } \\
\text { projects }\end{array}$ \\
\hline Du et al. (2019) & $\begin{array}{l}\text { (1) success }(0,1) \\
\text { (2) backing centroid }\end{array}$ & $\begin{array}{l}\text { Project's characteristics: number of } \\
\text { rewards options }\end{array}$ & $\begin{array}{l}\text { goal, duration, image number, } \\
\text { video }(0,1) \text {, category, start year, } \\
\text { start month, start week, } \\
\text { province, the number of } \\
\text { completed projects of creators, } \\
\text { the rate of success for the } \\
\text { completed projects of creators. }\end{array}$ & $\begin{array}{l}\text { The number of reward options has an } \\
\text { inverted U-shaped relationship with the } \\
\text { backers' decision. }\end{array}$ & $\begin{array}{l}\text { Zhongchou } \\
\text { (China) }\end{array}$ & 10,621 \\
\hline $\begin{array}{l}\text { Hong and Ryu } \\
\text { (2019) [100] }\end{array}$ & $\begin{array}{l}\text { (1) success rate } \\
\text { (2) funding amount }\end{array}$ & $\begin{array}{l}\text { Project's characteristics: } \\
\text { government support }(0,1) \\
\text { transparency }\end{array}$ & $\begin{array}{l}\text { duration, goal, "keep-it-all" } \\
\text { type. }\end{array}$ & $\begin{array}{l}\text { (1) Crowdfunding projects with } \\
\text { government involvement achieved a } \\
\text { greater success rate and attracted a greater } \\
\text { amount of funding than comparable } \\
\text { projects without government involvement. } \\
\text { (2) The positive impact of government } \\
\text { support on crowdfunding success rates or } \\
\text { funding amounts is significantly greater } \\
\text { when the transparency level of the project } \\
\text { is relatively low. } \\
\text { (3) Transparency is positively related to } \\
\text { crowdfunding success or } \\
\text { funding amounts. }\end{array}$ & Wadiz (Korea) & 110 \\
\hline
\end{tabular}


Table A1. Cont.

\begin{tabular}{|c|c|c|c|c|c|c|}
\hline Author (Year) & DV & Antecedents & Controls & Key Findings & Data Source & DataSize \\
\hline $\begin{array}{c}\text { Xie et al. (2019) } \\
\text { [101] }\end{array}$ & funding amount & $\begin{array}{l}\text { (1) Project's characteristics: funding } \\
\text { target, number of investors, price } \\
\text { ratio, upper limit } \\
\text { (2) Creator's characteristics: } \\
\text { number of followers }\end{array}$ & l & $\begin{array}{l}\text { (1) A significant positive relationship } \\
\text { exists between funding amount and } \\
\text { funding target. } \\
\text { (2) The number of investors and } \\
\text { number of followers have a positive } \\
\text { effect on funding amount. But } \\
\text { number of followers is negatively } \\
\text { correlated with funding amount in } \\
\text { the category of Games and Books. } \\
\text { (3) Price ratio and upper limit are all } \\
\text { positively associated with funding } \\
\text { amount. }\end{array}$ & $\begin{array}{l}\text { Taobao } \\
\text { (China) }\end{array}$ & 5128 \\
\hline $\begin{array}{l}\text { Larrea et al. } \\
(2019)[31]\end{array}$ & success rate & $\begin{array}{l}\text { (1) Information description } \\
\text { quantity: number of words, number } \\
\text { of images, number of videos; } \\
\text { quality: number of updates; } \\
\text { attitude: number of comments } \\
\text { (2) Project's characteristics: } \\
\text { community orientation, structural } \\
\text { characteristics of rewards }\end{array}$ & goal, duration, staff pick & $\begin{array}{l}\text { Community orientation, images that } \\
\text { show elements of the restaurant } \\
\text { concept, and frequent } \\
\text { communication with funders are key } \\
\text { drivers for success. }\end{array}$ & Kickstarter & 1567 \\
\hline $\begin{array}{l}\text { Gallemore et al. } \\
\text { (2019) [14] }\end{array}$ & $\begin{array}{l}\text { crowdfunding } \\
\text { success }(0,1)\end{array}$ & $\begin{array}{l}\text { (1) Project's characteristics: spatial } \\
\text { capital (median income, Northwest } \\
\text { Regional Center for Rural } \\
\text { Development's county-level social } \\
\text { capital index) } \\
\text { (2) Creator's characteristics: } \\
\text { cultural capital(prior campaigns, } \\
\text { funded prior campaigns), social } \\
\text { capital(team member degree), } \\
\text { economic capital(team size) }\end{array}$ & $\begin{array}{l}\text { funded in region, total } \\
\text { population, non-white } \\
\text { population, population 18-39, } \\
\text { isolate, goal, flexible funding }\end{array}$ & $\begin{array}{l}\text { Spatial context mediates the } \\
\text { relationship between resources and } \\
\text { success. Rural areas, in particular, } \\
\text { have lower success rates than urban } \\
\text { areas, and affluent areas have the } \\
\text { highest success rates. }\end{array}$ & Indiegogo & 134,098 \\
\hline $\begin{array}{c}\text { Yin et al. (2019) } \\
\text { [37] }\end{array}$ & success ratio & $\begin{array}{l}\text { (1) Information description-quality: } \\
\text { project updates } \\
\text { (2) Project's characteristics: goal } \\
\text { setting, reward levels, social media } \\
\text { usage, funds pledge, onsite } \\
\text { communication }\end{array}$ & $\begin{array}{l}\text { lowest pledge reward, highest } \\
\text { pledge reward, duration }\end{array}$ & $\begin{array}{l}\text { (1) Funds pledge has an inverse } \\
\text { U-shaped relationship with degree } \\
\text { of project success. } \\
\text { (2) Project updates, reward levels } \\
\text { and on-site communication } \\
\text { positively influence degree of project } \\
\text { success, while funding goal } \\
\text { negatively affects degree of project } \\
\text { success. }\end{array}$ & Kickstarter & 28,447 \\
\hline
\end{tabular}


Table A1. Cont.

\begin{tabular}{|c|c|c|c|c|c|c|}
\hline Author (Year) & DV & Antecedents & Controls & Key Findings & Data Source & DataSize \\
\hline $\begin{array}{c}\text { Lee et al. (2019) } \\
\text { [102] }\end{array}$ & $\begin{array}{l}\text { crowdfunding } \\
\text { success }(0,1)\end{array}$ & $\begin{array}{l}\text { Information description language: } \\
\text { psychological languages (positive } \\
\text { affective language, social language, } \\
\text { perceptual language), issue-relevant } \\
\text { content (quantitative language, risk } \\
\text { language, achievement language) }\end{array}$ & $\begin{array}{l}\text { Facebook friends, comments, } \\
\text { backers, length of pitch, } \\
\text { concrete language, certainty } \\
\text { language, male reference, } \\
\text { discrepancy, language intensity }\end{array}$ & $\begin{array}{l}\text { (1) Funding outcomes can be } \\
\text { improved with psychological } \\
\text { language dimensions (i.e., positive } \\
\text { affective and perceptual language). } \\
\text { However, extensive use of social } \\
\text { language does not help project } \\
\text { creators to increase their chance of } \\
\text { funding performance; but instead, } \\
\text { such language reduces the likelihood } \\
\text { of project success. } \\
\text { (2) Issue-relevant information such } \\
\text { as money and risk language } \\
\text { negatively influences funding } \\
\text { outcome. }\end{array}$ & $\begin{array}{l}\text { Spacehive } \\
\text { (UK) }\end{array}$ & 308 \\
\hline $\begin{array}{l}\text { Shahab et al. } \\
\text { (2019) [17] }\end{array}$ & number of backers & $\begin{array}{l}\text { (1) Creator's characteristics: } \\
\text { Feedback score, followers on Weibo } \\
\text { (2) Project's characteristics: project } \\
\text { sharing on social media } \\
\text { (3) Information description quality: } \\
\text { number of updates; quantity: videos } \\
(0,1) \text {, images }(0,1)\end{array}$ & goal, duration, category & $\begin{array}{l}\text { Feedback score, social capital } \\
\text { (followers on Weibo, project sharing } \\
\text { on social media) and project quality } \\
\text { (number of updates) are key } \\
\text { motivating factors in investment } \\
\text { decision and subsequently, project } \\
\text { success or failure. }\end{array}$ & $\begin{array}{l}\text { Demohour } \\
\text { (China) }\end{array}$ & 620 \\
\hline $\begin{array}{l}\text { Yeh et al. (2019) } \\
\text { [32] }\end{array}$ & $\begin{array}{l}\text { crowdfunding } \\
\text { success }(0,1)\end{array}$ & $\begin{array}{l}\text { (1) Information description } \\
\text { quantity: text description(number of } \\
\text { words),images description(number } \\
\text { of pictures); quality: update } \\
\text { frequency } \\
\text { (2) Creator's characteristics: } \\
\text { Facebook friends, past experience, } \\
\text { donation other projects, projector } \\
\text { response } \\
\text { (3) Project's characteristics: formal } \\
\text { website, numbers of reward }\end{array}$ & $\begin{array}{l}\text { location (nationality: Taiwan or } \\
\text { Japan) }\end{array}$ & $\begin{array}{l}\text { (1) Media richness factors (including } \\
\text { text description and images } \\
\text { description, signaling (including } \\
\text { founder response, updates frequency } \\
\text { and having a formal website) and } \\
\text { kindness (including donation to } \\
\text { other projects and rewarding } \\
\text { sponsors) obviously and positively } \\
\text { influence funding success. } \\
\text { (2) Past experiences of the founder } \\
\text { do not influence funding success. }\end{array}$ & $\begin{array}{l}\text { Zeczec } \\
\text { (Taiwan) } \\
\text { FlyingV } \\
\text { (Taiwan) } \\
\text { Campfire } \\
\text { (Japan) } \\
\text { Makuake } \\
\text { (Japan) }\end{array}$ & 323 \\
\hline $\begin{array}{l}\text { Usman et al. } \\
\text { (2019) [34] }\end{array}$ & $\begin{array}{l}\text { crowdfunding } \\
\text { success: fully funded, } \\
\text { the number of } \\
\text { backers, and funding } \\
\text { amount }\end{array}$ & $\begin{array}{l}\text { (1) Information description } \\
\text { quantity: media (video or image, } \\
0-3 \text { ) } \\
\text { (2) Creator's characteristics: } \\
\text { founder's past success }\end{array}$ & $\begin{array}{l}\text { duration, updates }(0,1) \text {, } \\
\text { comments, URL links, length of } \\
\text { context }\end{array}$ & $\begin{array}{l}\text { The study finds the positive } \\
\text { influence of quality signals (role of } \\
\text { media and founders past success) on } \\
\text { crowdfunding success. }\end{array}$ & $\begin{array}{l}\text { Crowdfunder } \\
\text { (UK) }\end{array}$ & 14,887 \\
\hline
\end{tabular}


Table A1. Cont.

\begin{tabular}{|c|c|c|c|c|c|c|}
\hline Author (Year) & DV & Antecedents & Controls & Key Findings & Data Source & DataSize \\
\hline $\begin{array}{l}\text { Yang et al. } \\
\text { (2019) [8] }\end{array}$ & $\begin{array}{l}\text { project success (the } \\
\text { ratio of the actual } \\
\text { collected funding } \\
\text { divide target funding } \\
\text { goal) }\end{array}$ & $\begin{array}{l}\text { Project's characteristics: funds } \\
\text { pledge, goal setting (including } \\
\text { square term), duration (including } \\
\text { square term) }\end{array}$ & l & $\begin{array}{l}\text { (1) The effect of goal setting on } \\
\text { project success is non-linear as low } \\
\text { and moderate levels of goal setting } \\
\text { are not always likely to have a } \\
\text { significant impact on project success, } \\
\text { but the presence of a higher goal is } \\
\text { likely to exert a positive effect on } \\
\text { project success. } \\
\text { (2) The effect of project duration on } \\
\text { project success is non-linear as short } \\
\text { and moderate levels of duration is } \\
\text { not always certain to have significant } \\
\text { impact on project success, but the } \\
\text { presence of a long duration is likely } \\
\text { to exert a positive effect on project } \\
\text { success. } \\
\text { (3) Funds pledge has positive effects } \\
\text { on project success. }\end{array}$ & $\begin{array}{c}\text { Tencent } \\
\text { Lejuan (China) }\end{array}$ & 1389 \\
\hline This study & $\begin{array}{l}\text { crowdfunding } \\
\text { success }(0,1)\end{array}$ & $\begin{array}{l}\text { (1) Information description } \\
\text { quantity: word count, word count } \\
\text { square, picture count, video count } \\
\text { (2) Information description quality: } \\
\text { readability, update } \\
\text { (3) Information description } \\
\text { attitude: comment }\end{array}$ & $\begin{array}{l}\text { experience as creator, } \\
\text { experience as backer, Facebook, } \\
\text { external websites, goal, } \\
\text { duration, category, country, } \\
\text { start year, start month, number } \\
\text { of rewards }\end{array}$ & $\begin{array}{l}\text { (1) Word count is associated with } \\
\text { crowdfunding success in an } \\
\text { inverted-U shape. } \\
\text { (2) Picture count, video count, } \\
\text { comment, and update have positive } \\
\text { effects on crowdfunding success. } \\
\text { (3) Readability is negatively related } \\
\text { to crowdfunding success. } \\
\text { (4) Comment negatively moderates } \\
\text { the effect of picture count on } \\
\text { crowdfunding success. }\end{array}$ & Kickstarter & 7207 \\
\hline
\end{tabular}




\section{References}

1. Mollick, E. The dynamics of crowdfunding: An exploratory study. J. Bus. Ventur. 2014, 29, 1-16. [CrossRef]

2. Allison, T.H.; Davis, B.C.; Webb, J.W.; Short, J.C. Persuasion in crowdfunding: An elaboration likelihood model of crowdfunding performance. J. Bus. Ventur. 2017, 32, 707-725. [CrossRef]

3. Belleflamme, P.; Lambert, T.; Schwienbacher, A. Crowdfunding: Tapping the right crowd. J. Bus. Ventur. 2014, 29, 585-609. [CrossRef]

4. Anglin, A.H.; Wolfe, M.T.; Short, J.C.; McKenny, A.F.; Pidduck, R.J. Narcissistic rhetoric and crowdfunding performance: A social role theory perspective. J. Bus. Ventur. 2018, 33, 780-812. [CrossRef]

5. Anglin, A.H.; Short, J.C.; Drover, W.; Stevenson, R.M.; McKenny, A.F.; Allison, T.H. The power of positivity? The influence of positive psychological capital language on crowdfunding performance. J. Bus. Ventur. 2018, 33, 470-492. [CrossRef]

6. Martínez-Climent, C.; Costa-Climent, R.; Oghazi, P. Sustainable Financing through Crowdfunding. Sustainability 2019, 11, 934. [CrossRef]

7. Li, Y.; Zhang, Z.; Wang, R.; Chen, Y. Consumer Purchase Intention toward Crowdfunding Products/Services: A Cost-Benefit Perspective. Sustainability 2019, 11, 3579. [CrossRef]

8. Yang, X.; Zhao, K.; Tao, X.; Shiu, E. Developing and Validating a Theory-Based Model of Crowdfunding Investment Intention-Perspectives from Social Exchange Theory and Customer Value Perspective. Sustainability 2019, 11, 2525. [CrossRef]

9. 2015CF Crowdfunding Industry Report. Available online: http://reports.crowdsourcing.org/index.php? route=product/product\&path=20\&product_id=54 (accessed on 15 May 2019).

10. Global Crowdfunding Market (2016-2020). Available online: http://crowdfundbeat.com/2016/02/03/reportglobal-crowdfunding-market-2016-2020/ (accessed on 15 June 2019).

11. Less Than a Third of Crowdfunding Campaigns Reach Their Goals. Available online: https://www. entrepreneur.com/article/269663 (accessed on 15 June 2019).

12. Zhou, M.J.; Lu, B.; Fan, W.P.; Wang, G.A. Project description and crowdfunding success: An exploratory study. Inf. Syst. Front. 2018, 20, 259-274. [CrossRef]

13. Davies, W.E.; Giovannetti, E. Signalling experience \& reciprocity to temper asymmetric information in crowdfunding evidence from 10,000 projects. Technol. Forecast. Soc. Chang. 2018, 133, 118-131.

14. Gallemore, C.; Nielsen, K.R.; Jespersen, K. The uneven geography of crowdfunding success: Spatial capital on Indiegogo. Environ. Plan. A Econ. Space 2019, 51, 1389-1406. [CrossRef]

15. Lagazio, C.; Querci, F. Exploring the multi-sided nature of crowdfunding campaign success. J. Bus. Res. 2018, 90, 318-324. [CrossRef]

16. Frydrych, D.; Bock, A.J.; Kinder, T.; Koeck, B. Exploring entrepreneurial legitimacy in reward-based crowdfunding. Ventur. Cap. 2014, 16, 247-269. [CrossRef]

17. Shahab, Y.; Ye, Z.; Riaz, Y.; Ntim, C.G. Individual's financial investment decision-making in reward-based crowdfunding: Evidence from China. Appl. Econ. Lett. 2019, 26, 261-266. [CrossRef]

18. Colombo, M.G.; Franzoni, C.; Rossi-Lamastra, C. Internal Social Capital and the Attraction of Early Contributions in Crowdfunding. Entrep. Theory Prac. 2015, 39, 75-100. [CrossRef]

19. Liao, C.; Zhu, Y.; Liao, X. The Role of Internal and External Social Capital in Crowdfunding: Evidence from China. Rev. Cercet. Interv. Soc. 2015, 49, 187-204.

20. Kang, L.; Jiang, Q.; Tan, C.-H. Remarkable advocates: An investigation of geographic distance and social capital for crowdfunding. Inf. Manag. 2017, 54, 336-348. [CrossRef]

21. Ahlers, G.K.C.; Cumming, D.; Günther, C.; Schweizer, D. Signaling in Equity Crowdfunding. Entrep. Theory Prac. 2015, 39, 955-980. [CrossRef]

22. Barbi, M.; Bigelli, M. Crowdfunding practices in and outside the US. Res. Int. Bus. Financ. 2017, 42, $208-223$. [CrossRef]

23. Kunz, M.M.; Bretschneider, U.; Erler, M.; Leimeister, J.M. An empirical investigation of signaling in reward-based crowdfunding. Electron. Commer. Res. 2016, 17, 425-461. [CrossRef]

24. Parhankangas, A.; Renko, M. Linguistic style and crowdfunding success among social and commercial entrepreneurs. J. Bus. Ventur. 2017, 32, 215-236. [CrossRef]

25. Dai, H.; Zhang, D.J. Prosocial Goal Pursuit in Crowdfunding: Evidence from Kickstarter. J. Mark. Res. 2019, 56, 498-517. [CrossRef] 
26. Zhang, H.; Chen, W. Crowdfunding technological innovations: Interaction between consumer benefits and rewards. Technovation 2019, 84, 11-20. [CrossRef]

27. Xu, L.Z. Will a digital camera cure your sick puppy? Modality and category effects in donation-based crowdfunding. Telemat. Inf. 2018, 35, 1914-1924. [CrossRef]

28. Shi, S.W. Crowdfunding: Designing an effective reward structure. Int. J. Mark. Res. 2018, 60, 288-303. [CrossRef]

29. Bi, S.; Liu, Z.; Usman, K. The influence of online information on investing decisions of reward-based crowdfunding. J. Bus. Res. 2017, 71, 10-18. [CrossRef]

30. Moy, N.; Chan, H.F.; Torgler, B. How much is too much? The effects of information quantity on crowdfunding performance. PLoS ONE 2018, 13, e0192012. [CrossRef]

31. De Larrea, G.L.; Altin, M.; Singh, D. Determinants of success of restaurant crowdfunding. Int. J. Hosp. Manag. 2019, 78, 150-158. [CrossRef]

32. Yeh, T.-L.; Chen, T.-Y.; Lee, C.-C. Investigating the funding success factors affecting reward-based crowdfunding projects. Innovation 2019, 21, 466-486. [CrossRef]

33. Courtney, C.; Dutta, S.; Li, Y. Resolving Information Asymmetry: Signaling, Endorsement, and Crowdfunding Success. Entrep. Theory Practic. 2017, 41, 265-290. [CrossRef]

34. Usman, S.M.; Bukhari, F.A.S.; Usman, M.; Badulescu, D.; Sial, M.S. Does the Role of Media and Founder's Past Success Mitigate the Problem of Information Asymmetry? Evidence from a UK Crowdfunding Platform. Sustainability 2019, 11, 692. [CrossRef]

35. Hobbs, J.; Grigore, G.; Molesworth, M. Success in the management of crowdfunding projects in the creative industries. Internet Res. 2016, 26, 146-166. [CrossRef]

36. Block, J.; Hornuf, L.; Moritz, A. Which updates during an equity crowdfunding campaign increase crowd participation? Small Bus. Econ. 2017, 50, 3-27. [CrossRef]

37. Yin, C.; Liu, L.; Mirkovski, K. Does more crowd participation bring more value to crowdfunding projects? The perspective of crowd capital. Internet Res. 2019, 29, 1149-1170. [CrossRef]

38. Wang, N.; Li, Q.; Liang, H.; Ye, T.; Ge, S. Understanding the importance of interaction between creators and backers in crowdfunding success. Electron. Commer. Res. Appl. 2018, 27, 106-117. [CrossRef]

39. Thies, F.; Wessel, M.; Benlian, A. Effects of Social Interaction Dynamics on Platforms. J. Manag. Inf. Syst. 2016, 33, 843-873. [CrossRef]

40. Petitjean, M. What explains the success of reward-based crowdfunding campaigns as they unfold? Evidence from the French crowdfunding platform KissKissBankBank. Financ. Res. Lett. 2018, 26, 9-14. [CrossRef]

41. Belleflamme, P.; Lambert, T.; Schwienbacher, A. Individual crowdfunding practices. Ventur. Cap. 2013, 15, 313-333. [CrossRef]

42. Estellés-Arolas, E.; González-Ladrón-de-Guevara, F. Towards an integrated crowdsourcing definition. J. Inf. Sci. 2012, 38, 189-200. [CrossRef]

43. Bayus, B.L. Crowdsourcing New Product Ideas over Time: An Analysis of the Dell IdeaStorm Community. Manag. Sci. 2013, 59, 226-244. [CrossRef]

44. Schwienbacher, A.; Larralde, B. Crowdfunding of small entrepreneurial ventures. In Handbook of Entrepreneurial Finance; Oxford University Press: Oxford, UK, 2010.

45. Wehnert, P.; Baccarella, C.V.; Beckmann, M. In crowdfunding we trust? Investigating crowdfunding success as a signal for enhancing trust in sustainable product features. Technol. Forecast. Soc. Chang. 2019, 141, 128-137. [CrossRef]

46. Gerber, E.M.; Hui, J.S.; Kuo, P.-Y. Crowdfunding: Why people are motivated to post and fund projects on crowdfunding platforms. In Proceedings of the International Workshop on Design, Influence, and Social Technologies: Techniques, Impacts and Ethics, Evanston, IL, USA, 11-15 February 2012; Volume 2, p. 10.

47. Allison, T.H.; Davis, B.C.; Short, J.C.; Webb, J.W. Crowdfunding in a Prosocial Microlending Environment: Examining the Role of Intrinsic Versus Extrinsic Cues. Entrep. Theory Pract. 2015, 39, 53-73. [CrossRef]

48. Huang, J.Q.; Chen, H.; Li, D. Research on factors influencing the success of crowd funding projects: The perspective of customer value. China Soft Sci. 2015, 6, 116-127.

49. Ryu, S.; Kim, Y.-G. A typology of crowdfunding sponsors: Birds of a feather flock together? Electron. Commer. Res. Appl. 2016, 16, 43-54. [CrossRef]

50. Bretschneider, U.; Leimeister, J.M. Not just an ego-trip: Exploring backers' motivation for funding in incentive-based crowdfunding. J. Strateg. Inf. Syst. 2017, 26, 246-260. [CrossRef]

51. Liu, D.; Brass, D.; Lu, Y.; Chen, D. Friendships in online peer-to-peer lending: Pipes, prisms, and relational herding. MIS Q. 2015, 39, 729-742. [CrossRef] 
52. Borst, I.; Moser, C.; Ferguson, J. From friendfunding to crowdfunding: Relevance of relationships, social media, and platform activities to crowdfunding performance. New Media Soc. 2018, 20, 1396-1414. [CrossRef]

53. Burtch, G.; Ghose, A.; Wattal, S. An Empirical Examination of the Antecedents and Consequences of Contribution Patterns in Crowd-Funded Markets. Inf. Syst. Res. 2013, 24, 499-519. [CrossRef]

54. Agrawal, A.; Catalini, C.; Goldfarb, A. Crowdfunding: Geography, Social Networks, and the Timing of Investment Decisions. J. Econ. Manag. Strategy 2015, 24, 253-274. [CrossRef]

55. Chen, J.J.; Zhang, Y.B.; Yin, Z.J. Study on Dynamics of Investors' Behavior in Crowdfunding Market-Evidence from Zhongchou Web. China Soft Sci. 2017, 9, 141-153.

56. Cumming, D.J.; Leboeuf, G.; Schwienbacher, A. Crowdfunding models: Keep-It-All vs. All-Or-Nothing. Financ. Manag. 2019, 1-30. [CrossRef]

57. Stiglitz, J.E. The contributions of the economics of information to twentieth century economics. Q. J. Econ. 2000, 115, 1441-1478. [CrossRef]

58. Spence, M. Competitive and optimal responses to signals: An analysis of efficiency and distribution. J. Econ. Theory 1973, 7, 296-332. [CrossRef]

59. Ross, S.A. The Determination of Financial Structure: The Incentive-Signalling Approach. Bell J. Econ. 1977, 8 , 23-40. [CrossRef]

60. Connelly, B.L.; Certo, S.T.; Ireland, R.D.; Reutzel, C.R. Signaling Theory: A Review and Assessment. J. Manag. 2010, 37, 39-67. [CrossRef]

61. Kromidha, E.; Robson, P. Social identity and signalling success factors in online crowdfunding. Entrep. Reg. Dev. 2016, 28, 605-629. [CrossRef]

62. Liu, C.; Liu, J. Antecedents of Success Rate of Award-Based Crowdfunding: The Case of the "Kickstarter". Mod. Econ. 2016, 7, 250-261. [CrossRef]

63. Escalas, J.E. Advertising narratives: What are they and how do they work. Represent. Consum. Voices Views Vis. 1998, 1, 267-289.

64. Du, Z.; Li, M.; Wang, K. The more options, the better? Investigating the impact of the number of options on backers' decisions in reward-based crowdfunding projects. Inf. Manag. 2019, 56, 429-444. [CrossRef]

65. Sundar, S.S. Multimedia effects on processing and perception of online news: A study of picture, audio, and video downloads. J. Mass Commun. Q. 2000, 77, 480-499. [CrossRef]

66. Appiah, O. Rich Media, Poor Media: The Impact of Audio/Video vs. Text/Picture Testimonial Ads on Browsers'Evaluations of Commercial Web Sites and Online Products. J. Curr. Issues Res. Advert. 2006, 28, 73-86. [CrossRef]

67. Kronrod, A.; Grinstein, A.; Wathieu, L. Enjoy! Hedonic Consumption and Compliance with Assertive Messages. J. Consum. Res. 2012, 39, 51-61. [CrossRef]

68. Klare, G.R. Assessing readability. Read. Res. Q. 1974, 10, 62-102. [CrossRef]

69. Li, F. Annual report readability, current earnings, and earnings persistence. J. Account. Econ. 2008, 45, 221-247. [CrossRef]

70. Ghose, A.; Ipeirotis, P.G. Estimating the Helpfulness and Economic Impact of Product Reviews: Mining Text and Reviewer Characteristics. IEEE Trans. Knowl. Data Eng. 2011, 23, 1498-1512. [CrossRef]

71. Fang, B.; Ye, Q.; Kucukusta, D.; Law, R. Analysis of the perceived value of online tourism reviews: Influence of readability and reviewer characteristics. Tour. Manag. 2016, 52, 498-506. [CrossRef]

72. Park, D.-H.; Kim, S. The effects of consumer knowledge on message processing of electronic word-of-mouth via online consumer reviews. Electron. Commer. Res. Appl. 2008, 7, 399-410. [CrossRef]

73. Schlosser, A.E. Can including pros and cons increase the helpfulness and persuasiveness of online reviews? The interactive effects of ratings and arguments. J. Consum. Psychol. 2011, 21, 226-239. [CrossRef]

74. Pan, Y.; Zhang, J.Q. Born Unequal: A Study of the Helpfulness of User-Generated Product Reviews. J. Retail. 2011, 87, 598-612. [CrossRef]

75. Olshavsky, R.W.; Granbois, D.H. Consumer Decision Making-Fact or Fiction? J. Consum. Res. 1979, 6, 93-100. [CrossRef]

76. Park, D.-H.; Lee, J.; Han, I. The Effect of On-Line Consumer Reviews on Consumer Purchasing Intention: The Moderating Role of Involvement. Int. J. Electron. Commer. 2014, 11, 125-148. [CrossRef]

77. Yang, M.; Qi, W.; Yan, X.B. Utility analysis for online product review. J. Manag. Sci. China 2012, 15, 65-75.

78. Lee, E.-J.; Shin, S.Y. When do consumers buy online product reviews? Effects of review quality, product type, and reviewer's photo. Comput. Hum. Behav. 2014, 31, 356-366. [CrossRef] 
79. Cumming, D.J.; Hornuf, L.; Karami, M.; Schweizer, D. Disentangling crowdfunding from fraudfunding. Max Planck Inst. Innov. Compet. Res. Pap. 2016, 8, 1-84. [CrossRef]

80. Butticè, V.; Colombo, M.G.; Wright, M. Serial Crowdfunding, Social Capital, and Project Success. Entrep. Theory Pract. 2017, 41, 183-207. [CrossRef]

81. Cholakova, M.; Clarysse, B. Does the Possibility to Make Equity Investments in Crowdfunding Projects Crowd Out Reward-Based Investments? Entrep. Theory Pract. 2015, 39, 145-172. [CrossRef]

82. Davis, B.C.; Hmieleski, K.M.; Webb, J.W.; Coombs, J.E. Funders' positive affective reactions to entrepreneurs' crowdfunding pitches: The influence of perceived product creativity and entrepreneurial passion. J. Bus. Ventur. 2017, 32, 90-106. [CrossRef]

83. Green, M.C.; Brock, T.C. In the mind's eye: Transportation-imagery model of narrative persuasion. In Narrative Impact: Social and Cognitive Foundations; Lawrence Erlbaum Associates Publishers: Mahwah, NJ, USA, 2002.

84. Pietraszkiewicz, A.; Soppe, B.; Formanowicz, M. Go Pro Bono. Soc. Psychol. 2017, 48, 265-278. [CrossRef]

85. Mollick, E.; Robb, A. democratizing innovation and capital access: the role of crowdfunding. Calif. Manag. Rev. 2016, 58, 72-87. [CrossRef]

86. Greenberg, J.; Mollick, E. Activist Choice Homophily and the Crowdfunding of Female Founders. Adm. Sci. Q. 2016, 62, 341-374. [CrossRef]

87. Aiken, L.S.; West, S.G. Multiple Regression: Testing and Interpreting Interactions; Sage: Newbury Park, CA, USA, 1991.

88. Chen, X.P.; Yao, X.; Kotha, S. Entrepreneur Passion and Preparedness in Business Plan Presentations: A Persuasion Analysis of Venture Capitalists' Funding Decisions. Acad. Manag. J. 2009, 52, 199-214. [CrossRef]

89. Clauss, T.; Breitenecker, R.J.; Kraus, S.; Brem, A.; Richter, C. Directing the wisdom of the crowd: The importance of social interaction among founders and the crowd during crowdfunding campaigns. Econ. Innov. New Technol. 2018, 27, 709-729. [CrossRef]

90. Sauermann, H.; Franzoni, C.; Shafi, K. Crowdfunding scientific research: Descriptive insights and correlates of funding success. PLoS ONE 2019, 14, e0208384. [CrossRef]

91. Calic, G.; Mosakowski, E. Kicking Off Social Entrepreneurship: How A Sustainability Orientation Influences Crowdfunding Success. J. Manag. Stud. 2016, 53, 738-767. [CrossRef]

92. Chen, S.; Thomas, S.; Kohli, C. What Really Makes a Promotional Campaign Succeed on a Crowdfunding Platform?Guilt, Utilitarian Products, Emotional Messaging, and Fewer but Meaningful Rewards, Drive Donations. J. Adv. Res. 2016, 56, 81-94. [CrossRef]

93. Kim, P.H.; Buffart, M.; Croidieu, G. TMI: Signaling Credible Claims in Crowdfunding Campaign Narratives. Gr. Organ. Manag. 2016, 41,717-750. [CrossRef]

94. Chan, C.S.R.; Park, H.D.; Patel, P.; Gomulya, D. Reward-based crowdfunding success: Decomposition of the project, product category, entrepreneur, and location effects. Ventur. Capit. 2018, 20, 285-307. [CrossRef]

95. Gafni, H.; Marom, D.; Sade, O. Are the life and death of an early-stage venture indeed in the power of the tongue? Lessons from online crowdfunding pitches. Strateg. Entrep. J. 2019, 13, 3-23. [CrossRef]

96. Guo, L.; Guo, D.; Wang, W.; Wang, H.; Wu, Y. Distance Diffusion of Home Bias for Crowdfunding Campaigns between Categories: Insights from Data Analytics. Sustainability 2018, 10, 1251. [CrossRef]

97. Schafer, M.S.; Metag, J.; Feustle, J.; Herzog, L. Selling science 2.0: What scientific projects receive crowdfunding online? Public Underst. Sci. 2018, 27, 496-514. [CrossRef]

98. Vismara, S. Sustainability in equity crowdfunding. Technol. Forecast. Soc. Chang. 2019, 141, 98-106. [CrossRef]

99. Chan, H.F.; Moy, N.; Schaffner, M.; Torgler, B. The effects of money saliency and sustainability orientation on reward based crowdfunding success. J. Bus. Res. in press.

100. Hong, S.; Ryu, J. Crowdfunding public projects: Collaborative governance for achieving citizen co-funding of public goods. Gov. Inf. Q. 2019, 36, 145-153. [CrossRef]

101. Xie, K.; Liu, Z.; Chen, L.; Zhang, W.; Liu, S.; Chaudhry, S.S. Success factors and complex dynamics of crowdfunding: An empirical research on Taobao platform in China. Electron. Mark. 2018, 29, 187-199. [CrossRef]

102. Lee, C.H.; Bian, Y.; Karaouzene, R.; Suleiman, N. Examining the role of narratives in civic crowdfunding: Linguistic style and message substance. Ind. Manag. Data Syst. 2019, 119, 1492-1514. [CrossRef]

(C) 2020 by the authors. Licensee MDPI, Basel, Switzerland. This article is an open access article distributed under the terms and conditions of the Creative Commons Attribution (CC BY) license (http://creativecommons.org/licenses/by/4.0/). 